See discussions, stats, and author profiles for this publication at: https://www.researchgate.net/publication/260332847

\title{
Reconstruction of topography and related systems during active thrusting
}

Article in Journal of Geophysical Research Atmospheres · October 1994 DOI: 10.1029/94JB00463

CITATIONS

127

2 authors:

Douglas W. Burbank

University of California, Santa Barbara

287 PUBLICATIONS 20,945 CITATIONS

SEE PROFILE
READS

119

Some of the authors of this publication are also working on these related projects:

Project Topographic response to lateral changes in subduction polarity View project

Project Fluid Flow in the Pyrenean Fold Belt View project 


\title{
Reconstruction of topography and related depositional systems during active thrusting
}

\author{
Douglas W. Burbank \\ Department of Geological Sciences, University of Southem Califomia, Los Angeles
}

Jaume Vergés

Departamento de Geologia Dinàmica, Geofísica, i Paleontologia, University of Barcelona, Barcelona, Spain

\begin{abstract}
Reliable reconstruction of former topography in deformed regions is commonly difficult, due to degradation of former erosional and depositional surfaces. In contrast to most modem landscapes, however, ancient localities can sometimes provide clearer insights on subsurface geometries of deposition, deformation, and erosion and on their variations through time. In some exceptional circumstances, ancient depositional sequences are preserved in direct juxtaposition with the structures that controlled their geometrical and sedimentological character. We describe here the evolving topography and depositional responses caused by the late Eocene growth of a detachment fold and related thrusts in the southern Pyrenees. Topography within these deforming systems can be reconstructed on the basis of (1) relief associated with paleovalleys, (2) geometric relationships of syntectonic strata with adjacent structures, and (3) relief of hanging walls above depositional or erosional surfaces of the same age. Onlapping, offlapping, and overlapping stratigraphic relationships are interpreted in the context of the relative rate of sediment accumulation versus the rate of uplift of the crest of the fold. In the study area, two contrasting fluvial systems provided sediment to the deforming area: a large longitudinal system, flowing parallel to the fold axes and carrying detritus from the distant hinterland, and a smaller transverse system that carried locally derived clasts. During fold growth, syntectonic sedimentary beds (growth strata) were progressively rotated in the forelimb of the fold. Proximal unconformities developed in the forelimb growth strata, when accumulation rates were low. Topographic relief on the backlimb of the growing fold caused transverse paleovalleys ( $>150 \mathrm{~m}$ deep) to be incised at high angles to the fold axis. A switch from incision to infilling of the paleovalleys appears to be controlled by relative rates of subsidence, sediment supply and accumulation, and uplift. During an interval of rapid accumulation and low rates of subsidence and uplift, the effects of rising local base levels propagated up the transverse valleys, where they initiated backfilling of the paleovalleys. As deformation began on an adjacent, more hinterlandward thrust, waning growth of the detachment fold permitted depositional overlap of its crest, as sedimentation shifted toward the hinterland. Subsequently, as the new footwall was folded, longitudinal rivers filled the space formerly occupied by transverse rivers, and a new detachment fold grew in the very shallow $(<25 \mathrm{~m})$ subsurface. Although similar examples are scarce in the geological record, the synthesis from this Pyrenean locale illustrates how stratal geometries, reconstructed river patterns, precise stratigraphic ages, and preserved erosional surfaces can be combined to reconstruct evolving topography during active folding and faulting in terrestrial environments.
\end{abstract}

\section{Introduction}

It is often straightforward to examine presently active tectonic environments and to understand the cause-and-effect relationships among tectonic activity, evolving topography, and sedimentation. Typically it is much more difficult to make reliable reconstructions of these interactions in the past. In order to answer questions concerning (1) the topography of the land surface at the time of deformation, (2) the courses of rivers with respect to structures, (3) the relative importance of local streams versus regionally extensive rivers, (4) the role of ongoing deformation in controlling deposition, and (5) the rates at which uplift, denudation, and deposition occurred, it is necessary to examine

Copyright 1994 by the American Geophysical Union.

Paper number $94 \mathrm{JB} 00463$.

0148-0227/94/94JB-00463\$05.00 the geometry, position, and age of syntectonic deposits, structures, and surfaces. Unfortunately, erosion frequently obliterates those strata that were deposited on the flanks of growing structures, and thus key elements needed for a topographic reconstruction are lost. In terrestrial strata, moreover, it is commonly difficult to determine precise ages for deformation and deposition, so that reconstructions of rates of past processes are often poorly known.

Reliable reconstructions of sequential changes in topography in actively deforming environments require the following types of data: well-exposed surficial or near-surface structures that developed during deposition; syntectonic deposits that are directly juxtaposed with those structures; clearly preserved erosional and depositional surfaces within the syntectonic deposits that define large-scale geometries of depositional units with respect to nearby structures and serve to delineate a sequence of deformational events; extensive two- and three-dimensional exposures 
with good lateral continuity to define relief along the former land surface; sedimentological data on provenance and paleoflow directions; reliable spatial reference frames within which to define comparative magnitudes and rates of processes; and precise time control on syntectonic deposition.

Few areas display all of these characteristics. In the southern Pyrenees of northern Spain, however, there are several localities characterized by shallow levels of erosion, excellent exposures, and preexisting magnetostratigraphic chronologies of terrestrial deposition [Burbank et al., 1992]. Here the Paleogene depositional systems, erosional surfaces, and related structures can be reconstructed in considerable detail. In this paper, we describe an example from the eastern oblique margin of the South-Central Unit (Figure 1) in the vicinity of Oliana [Vergés and Muñoz, 1990]. We focus on an asymmetric, south-vergent detachment fold which has a steeply dipping to overturned, southern limb (herein termed the forelimb) and a less steep limb on the hinterland side of the fold crest (the backlimb). Growth of the fold controlled the river patterns, the cutting and filling of paleovalleys, the local topographic relief, and the episodic shifting of the depocenter.

The detachment fold grew synchronously with a much larger fold to the south (the Oliana anticline) and was followed by renewed thrusting along the Montsec thrust, which is closer to the hinterland. New magnetic chronologies allow us to define rates of aggradation and related fold growth, whereas detailed mapping and sedimentologic studies provide insights on the interactions between tectonics, sedimentation, and topography adjacent to the fold. In this study, we use nearly horizontal, original depositional surfaces as reference frames in order to track the progressive growth of folds, the rotation of beds, the depths of incision, and changes in the relative rates of subsidence. Provenance studies, paleocurrent orientations, and sedimentological characteristics permit us to reconstruct the depositional systems and understand their interactions with the deforming folds and thrusts.

Our interpretations yield a four-stage history for this area (Figure 2). In response to growth of a detachment fold, strata fed by rivers flowing parallel to the fold axis accumulate in the fold's forelimb, taper toward the fold, and are continuously rotated by folding (unit 2, Figure 2). At the same time, valleys transverse to the fold axis and up $150 \mathrm{~m}$ deep are incised through the eroding backlimb of the fold and adjacent hanging wall strata. Because the transverse valleys are graded to the forelimb, when rates of sediment accumulation markedly increase in the forelimb, the valleys being to fill with locally derived conglomerates. As fold growth stops, deformation shifts to a more hinterlandward thrust, rivers flowing parallel to the thrust trace overlap the older fold axis (unit 3, Figure 2). Subsequently, motion on the thrust causes folding of its footwall, and the depocenter shifts toward a more distal position (unit 4, Figure 2). Topographic relief at each stage

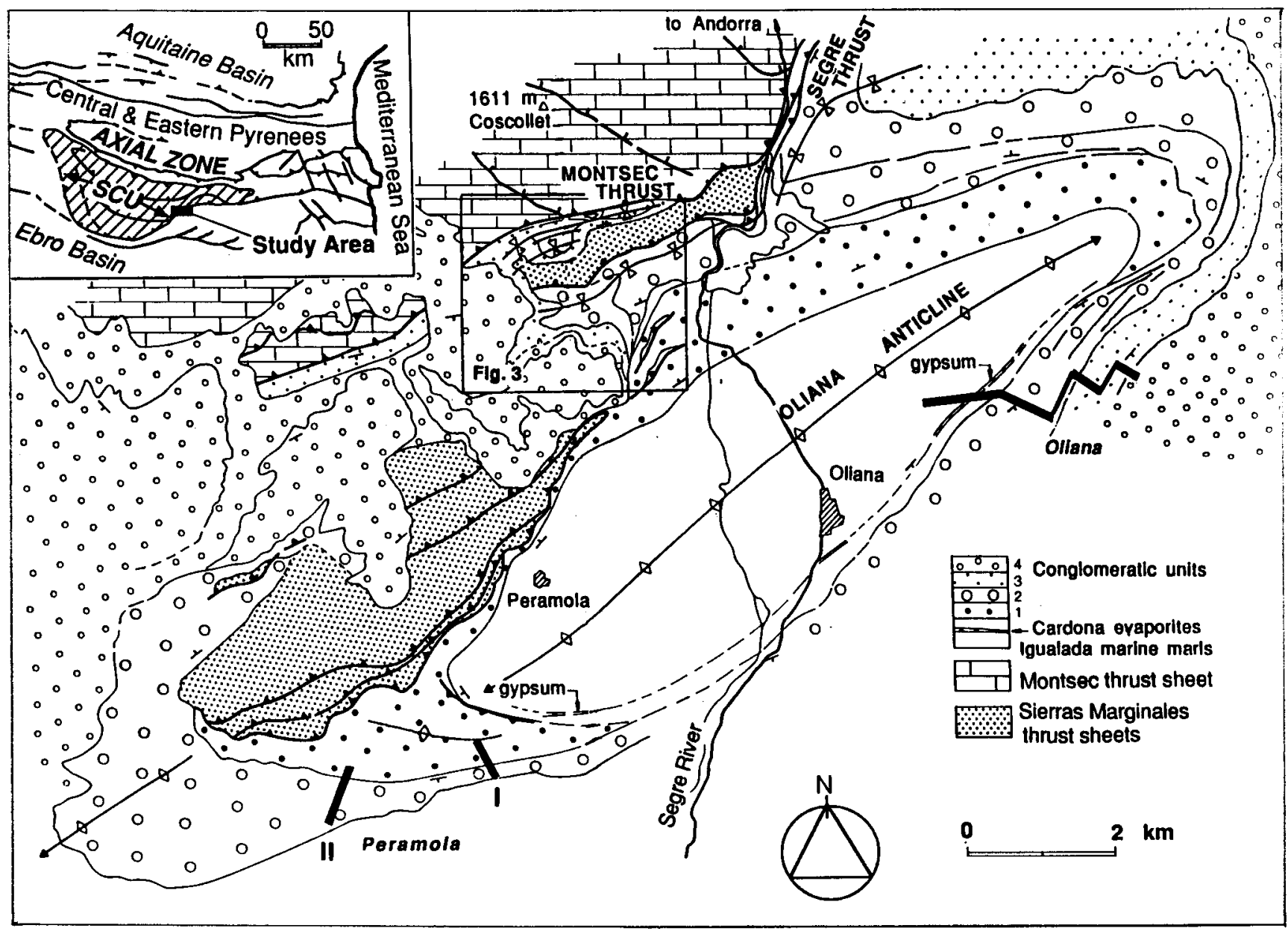

Figure 1. Simplified geologic map showing major thrusts and stratigraphic units within the Oliana area. The locations of the master magnetostratigraphic section [from Burbank et al., 1992] and the studied area (Figure 3) are shown. Inset shows a generalized map of the Pyrences. The study area is located astride the eastern oblique margin of the South Central Unit (SCU). 
Before 36.6 Ma (36.4 Ma)

Section A-A'

A.

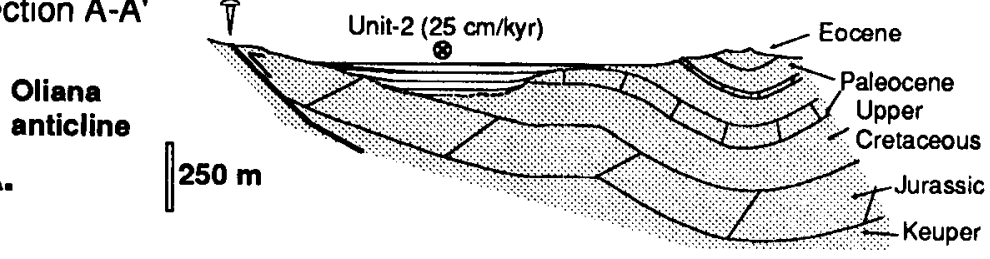

Section B-B'

Unit-2 (36.4-35.7 Ma $=6 \mathrm{~cm} / \mathrm{kyr})$

B.

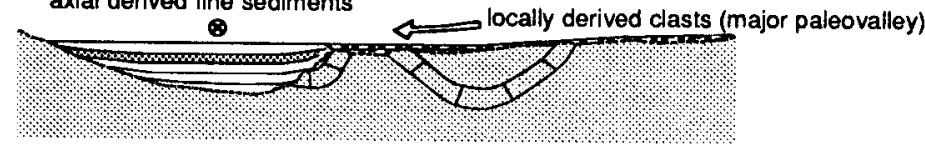

Section A-A'

36.4-35 Ma

C.
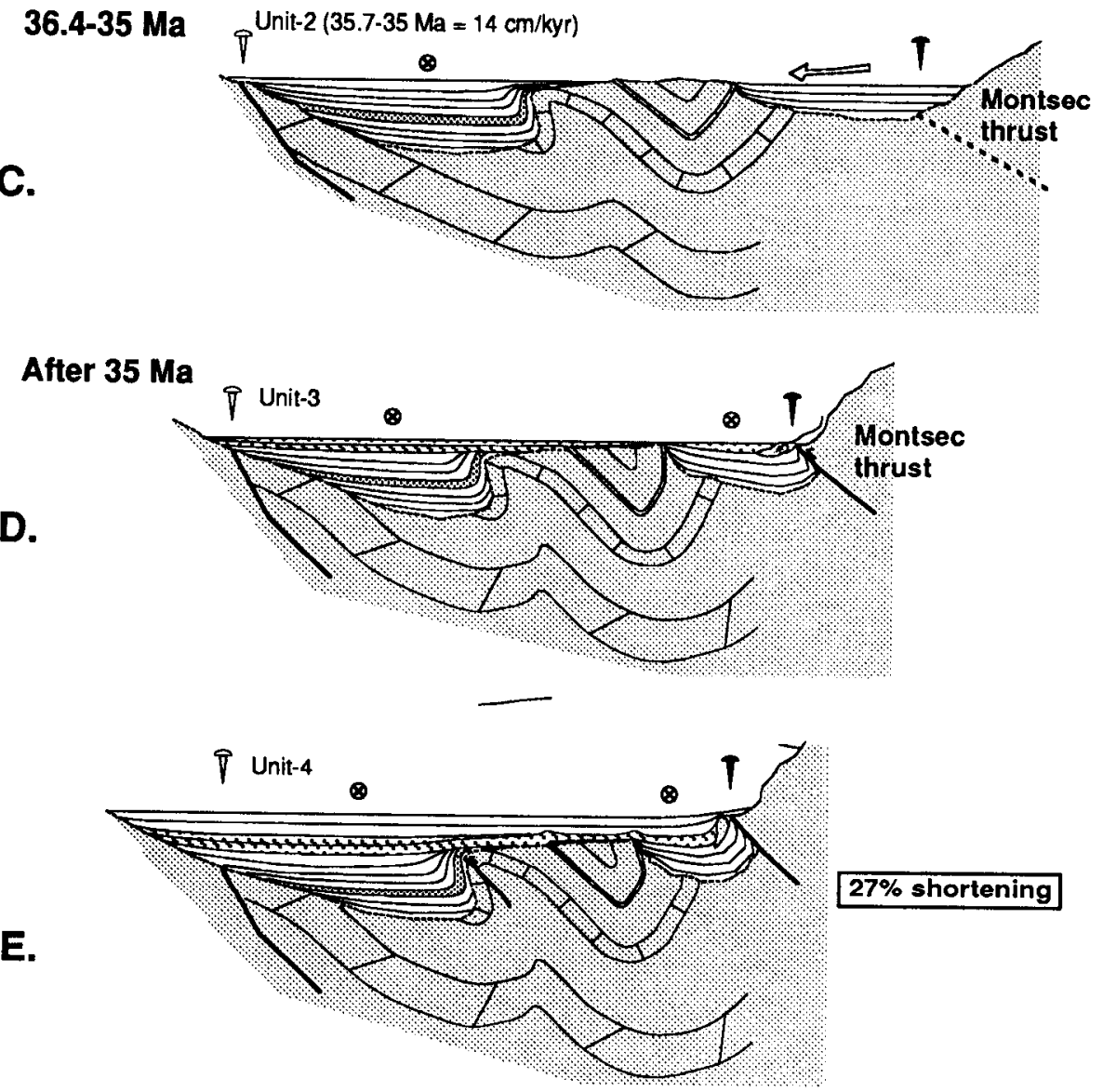

Figure 2. Sequential reconstruction of deformational and depositional patterns of units 2 to 4 in the hanging wall of the Serres Marginals thrust sheet. Reconstructions are based magnetostratigraphic dates and on growth strata, bed lengths, and geometries of preserved erosional and depositional surfaces. (a) Unit 2 is deposited by a longitudinal river in a developing growth syncline. (b) Unit 2 is deposited in the growth syncline, and the crest of the detachment fold is breached by a transverse paleovalley $>150 \mathrm{~m}$ deep. (c) Transverse valley begins to fill with locally derived clasts as the rate of uplift of the detachment fold decreases and accumulation in the growth syncline accelerates. (d) Unit 3 overlaps the detachment fold after the paleovalley is filled. The Montsec thrust is reactivated and a megaclast is incorporated in the footwall syncline. (e) Depocenter shifts farther toward the foreland as the footwall continues to be uplifted. For locations of cross sections A-A' and B-B', see Figure 3 . 
can be defined by the height differences between the depositional surfaces and preserved erosional topography nearby.

\section{Geologic Setting}

The South Central Unit (SCU) [Séguret, 1972] comprises an imbricate system of emergent thrusts (from north to south: the Boixols, Montsec, and Serres Marginals thrusts, Figure 1) which display an overall piggyback sequence of thrusting during latest Cretaceous to early Eocene times. Subsequent southward transport over the foreland deposits is recorded by middle Eocene to Oligocene syntectonic strata [Vergés and Burbank, 1994]. Coeval with this southward transport, older hinterland thrusts were reactivated, in both the central [Martinez-Peña and Pocoví, 1988; Muñoz, 1992; Puigdefàbregas et al., 1992] and eastern parts of the SCU (Figure 1) [Burbank et al., 1992; Vergés and Muñoz, 1990].

The study area is located along the eastern boundary of the SCU, where a set of oblique thrusts merge northward into a single thrust: the Segre thrust. The Oliana anticline is a $15-\mathrm{km}$ long, doubly plunging structure located in the footwall of and oblique to the Segre thrust. Formed by stacking two slices of Paleogene strata, the anticline is an allochthonous structure that was transported $10 \mathrm{~km}$ to the south across a decollement localized within the upper Eocene Cardona salt [Vergés and Muñoz, 1990; Vergés et al., 1991]. To the northwest of the Oliana anticline and coeval with its growth, synorogenic conglomerates that overlap and are cut by thrusts demonstrate that the Mesozoic rocks of the SCU in the hanging wall of the Segre thrust are deformed by break-back thrusts (i.e., a sequence of thrusting that becomes younger toward the hinterland) and related folds. Details of the thrust geometry, sequencing, age, and rates of shortening are given by Vergés and Muñoz [1990] and Burbank et al. [1992]. The present study describes the landscape evolution associated with growth of a detachment fold within the Serres Marginals thrust sheets and later shortening on the Montsec thrust. Both the fold and the hanging walls of these thrusts include Mesozoic and Paleogene strata (Figures 3 and 4).

\section{Methodology}

The study area was mapped in detail on aerial photographs and topographic maps at scales of $\sim 1: 16,000$ and $1: 25,000$, respec-

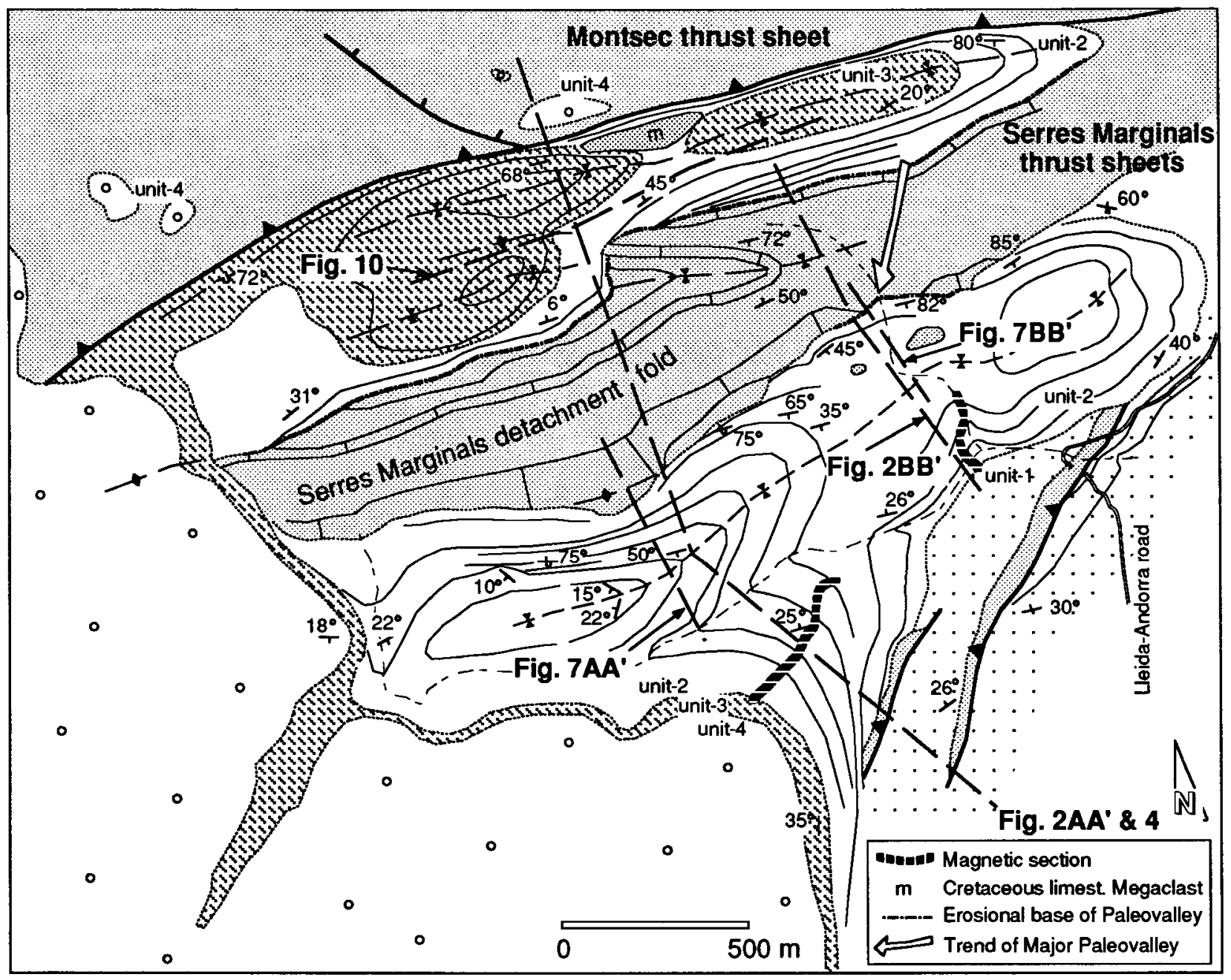

Figure 3. Geologic map of the syntectonic strata (units 1-4) associated with the Montsec and Serres Marginals thrust sheets (shaded). Growth synclines, as depicted by strike line mapping, occur in the footwall of the Montsec thrust and in the forelimb of the detachment fold in the Serres Marginals hanging wall. The bases of the paleovalleys and the breached crest of the detachment fold are shown. The large arrow depicts the trend of the now-eroded paleovalley across the detachment fold. Locations of the magnetic section and various cross sections are shown. 
SE

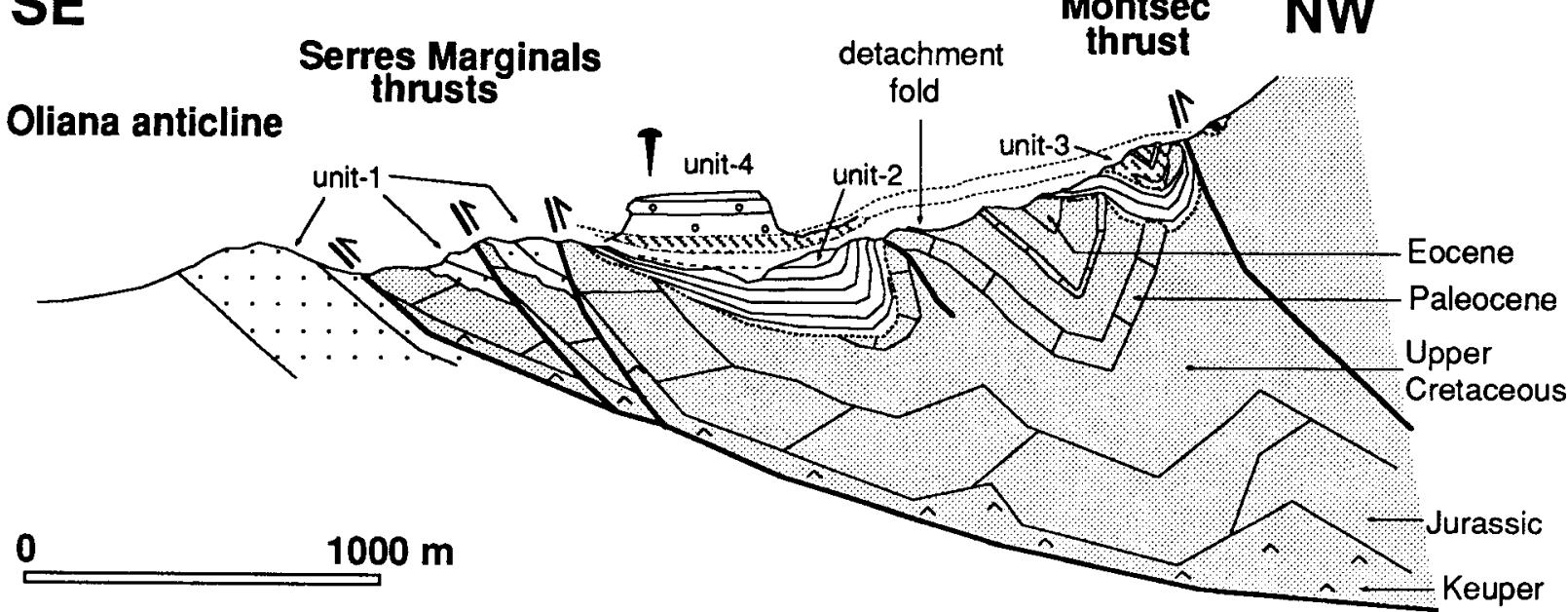

Figure 4. Structural cross section between the backlimb of the Oliana anticline and the Montsec thrust sheet. Major structures within the Serres Marginals hanging wall, including the detachment fold, and the geometries of the syntectonic conglomerates (units 1-4) define a break back (hinterlandward) sequence of thrusting. Differences in the amount of folding of the conglomerates and the underlying, older strata result from inheritance of previously formed structures. See Figure 3 for location of section.

tively. Sections were measured and described through each of the major depositional units, and data on facies, paleocurrents, and provenance were collected. The present geometry of former erosional and depositional surfaces was recorded and later restored to a predeformational position with respect to bedding surfaces that were assumed to have been essentially horizontal at the time of deposition. Samples for paleomagnetic studies were collected where fine grained strata were sufficiently abundant and sections were sufficiently long. These samples were processed through multiple levels of thermal demagnetization: a procedure used successfully in previous studies to create magnetostratigraphies in correlative strata on the flanks of the Oliana anticline (Figure 3 ). (For details of the magnetostratigraphic procedures, see Burbank et al. [1992].)

Interpretation of the growth strata is based in part on models that predict stratal geometries as a function of the relative rates of sediment accumulation versus crestal uplift (Figure 5). Crestal uplift is defined as the structural uplift plus or minus any deposition or erosion, respectively, over the crestal area of a fold. Crestal uplift thus defines changes in position of the highest surface of the fold and is differentiated from bedrock uplift [England and Molnar, 1990]. The reference level for measuring crestal uplift is either the position of correlative folded strata in the adjacent syncline or the base of the syntectonic strata in the adjacent basin. Although here we use crestal uplift rates, one could also interpret onlap-offlap geometries in the context of uplift rates of a site on the flanks of a fold.

\section{Syntectonic Deposition}

The upper Eocene to lower Oligocene stratigraphic succession [Burbank et al., 1992] is dominated by four, primarily conglomeratic sequences that are interleaved with various thrusts and deformed by the Oliana anticline (Figures 3 and 4). Because the oldest conglomerate (unit 1) is cut by the outermost Serres Marginals thrust, and the youngest conglomerate (unit 4) is only slightly deformed by the youngest (Montsec) thrust, these conglomerates and their associated finer grained strata bracket the late Eocene interval of break-back thrusting. Previously completed magnetostratigraphic studies [Burbank et al., 1992], when compared with the new time scale of Cande and Kent [1992], indicate that break-back thrusting and growth of the Oliana anticline occurred during latest Eocene times between $~ 37.2$ and 34.0 Ma. In this paper, we focus on units 2 and 3 which were deposited and deformed during the reactivation of folds and thrusts in the Serres Marginals and Montsec thrust sheets.

\section{Unit 2}

Unit 2 was deposited both on the forelimb of the detachment fold and across the intervening terrain between the fold crest and the Montsec thrust, including the backlimb of the detachment fold (Figures 2, 3, and 4). Exposed within the fold at present and in the footwall to the Montsec thrust are upper Cretaceous sandstone (Aren Formation), Paleocene red beds and lacustrine limestones (Garumnian Formation), and a thin sequence of lower Eocene nummulitic marls, limestones, sandstones. These stratigraphic units vary significantly in their resistance to erosion, and these differences have played important roles in controlling the topography during deformation. Today, thin fins of lacustrine limestone, the most resistant lithology, stand $10-20 \mathrm{~m}$ above the adjacent slopes and demarcate the margins of paleotopographic high spots in the landscape.

Those strata which predate the late Eocene deformational events are more strongly folded than are the syndeformational conglomerates that mantle them. This enhanced folding indicates that at the initiation of late Eocene deposition, moderate deformation had already occurred during early and/or middle Eocene folding [Vergés, 1993].

Unit 2 is preserved in three localities within the study area. The thickest accumulation occurs in a growth syncline in the forelimb of the detachment fold situated between a Serres Marginals thrust imbricate to the SE and the fold crest (Figures 3, 4 , and 6). The other occurrences are within two paleovalleys, 50 to $150 \mathrm{~m}$ deep, that were eroded in the backlimb of the detachment fold and in the Montsec footwall. All of these 


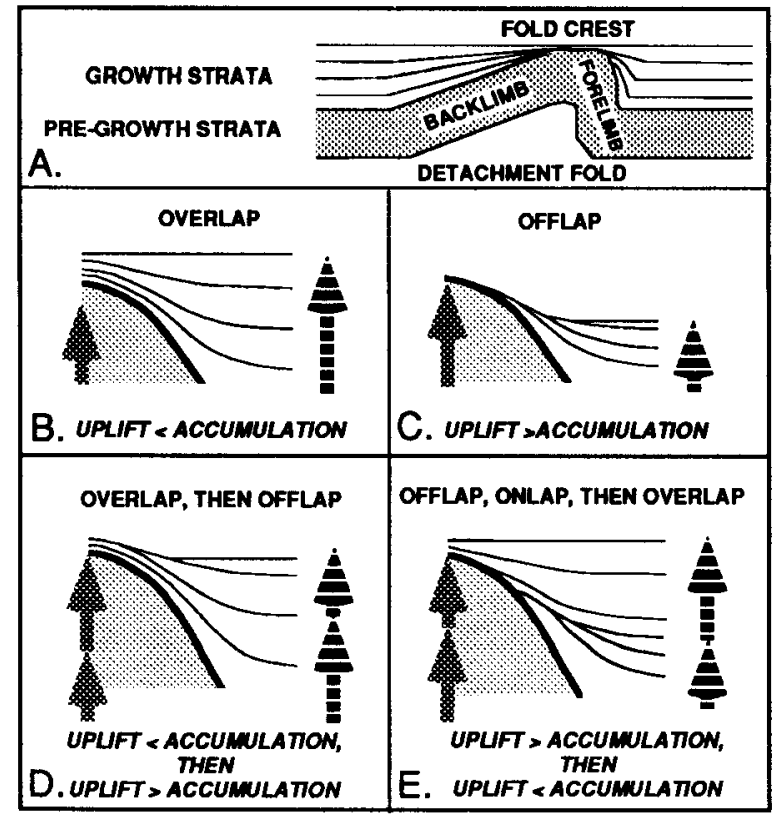

Figure 5. (a) Nomenclature for a detachment fold and growth strata deposited during folding. (b)-(e) Models of overlap, offlap, and onlap. Predictable geometries of syntectonic strata result from contrasts in the relative rates of crestal uplift versus coeval rates of accumulation. Crestal uplift is measured with respect to either (1) the base of the syntectonic strata adjacent to the fold or (2) the position of correlative marker beds found in both the anticline and the adjacent syncline. When rates of accumulation are consistently greater than the rate of crestal uplift, overlap will occur (Figure $5 \mathrm{~b}$ ), whereas lower rates of accumulation versus uplift lead to offlap (Figure 5c). Reversals in the relative magnitude of these rates causes a switch in the bedding geometry (Figure 5d). Onlap (Figure 5e) occurs following offlap and a change to more rapid accumulation rates.

occurrences lie between the hanging wall of the Montsec thrust and the backlimb of the Oliana anticline which was also growing during deposition (Figures 1 and 4 ).

Growth syncline. Unit 2 is at least $250 \mathrm{~m}$ thick within the axis of the growth syncline (Figure 7), but tapers rapidly toward the detachment fold and more gradually toward the backlimb of the Oliana anticline.

Sedimentology: Sedimentation here is dominated by belts of amalgamated channelized conglomerate separated by thin (1-5 $\mathrm{m})$, red siltstone and sandstone. Although most conglomeratic beds are $20-50 \mathrm{~cm}$ thick, individual beds can attain $5 \mathrm{~m}$ in thickness. The beds are broadly tabular but display small $(1-4 \mathrm{~m})$, inset channels. The conglomerates are clast supported, contain many pebbly lenses, and uncommonly display planar cross bedding. The clasts are well rounded and are heterolithic. Although dominated by clasts of Mesozoic carbonates that could be locally derived, unit 2 within the growth syncline also contains basement clasts derived from the Pyrenean "Axial Zone" $>30 \mathrm{~km}$ to the north. The conglomerates appear to be of wholly local origin only in localities within a few meters of the growing detachment fold. Paleocurrent directions $(N=113)$ based on clast imbrications, cross bedding, and numerous elongate "gutters" on the base of many conglomerate units (Figure 8) indicate that flow, across much of its extent, was to the SW, i.e., a longitudinal or axial flow direction [Burbank and Beck, 1991;
Eisbacher et al., 1974] parallel to the traces of the local thrusts and fold axes.

At the base of the succession on the folded forelimb, poorly bedded, unsorted, monolithologic breccias of angular clasts of Garumnian limestones in jig-saw-like geometries are present in places. In other sites, crudely bedded, subangular to subrounded conglomerates with large clasts of Garumnian limestones as much as $1 \mathrm{~m}$ in diameter occur.

Age: The results from 16 class I and II magnetic sites following stepwise thermal demagnetization indicate that at least three and probably six magnetic reversals are encompassed by unit 2 (Figure 8 ). In the context of the previously determined magnetostratigraphic framework for units 2 and 3 on the SE flank of the Oliana anticline [Burbank et al., 1992], this reversal pattern can be interpreted (Figure 8) to indicate that unit 2 was deposited between -36.7 and $35.0 \mathrm{Ma}$ [Cande and Kent, 1992]. These age limits yield mean compacted accumulation rates of $\sim 16 \mathrm{~cm} / \mathrm{kyr}$.

Geometrical relationships: Whereas tabular bedding geometries are displayed throughout much of its extent, beds within unit 2 clearly taper and are increasingly deformed toward both the SE and the NW (Figure 4). Although the depositional contacts of unit 2 with the underlying strata to the SE are not well exposed, folding of the beds and clear thinning of unit 2 toward the SE indicate that the backlimb of the Oliana anticline was steepening during deposition. Because the conglomeratic beds progressively onlap the flanks of the growing Oliana anticline, they indicate that the relative rate of flank uplift was less than the average rate $(\sim 16 \mathrm{~cm} / \mathrm{kyr}$ ) of sediment accumulation (Figure 5$)$, although the crestal uplift rate of the anticline was likely to have been considerably higher.

To the NW, unit 2 is juxtaposed against and incorporated in the forelimb of the detachment fold (Figure 6). Clear onlapping of the conglomerates with the pre-Eocene strata is seen along much of the exposed contact. During growth of this anticlinal fold, formerly subhorizontal depositional surfaces within unit 2 were progressively rotated, such that some older surfaces are presently overturned in the proximal parts of the growth syncline. A clear hinge line separates (1) the central area of unit 2 deposition in which stratal thicknesses are generally constant and beds are tabular from (2) the region adjacent to the anticline in which stratal thicknesses abruptly taper toward the anticline. Because these tapered strata are lateral continuations of adjacent tabular strata, comprise well rounded clasts, are largely fluvial in origin, and contain basement clasts even in many sites close to the fold, they represent part of an axial fluvial system flowing parallel to the fold axis and can be considered to have had subhorizontal upper surfaces at the time of deposition (with respect to the NW-SE cross section), rather than being sloping transverse fan surfaces.

Reconstructed history of deformation and deposition: Our interpretation of the magnetic data implies that sediment-accumulation rates varied strongly during deposition of unit 2 . In comparison to relative uplift rates on the flank of the fold, high rates of aggradation $(-25 \mathrm{~cm} / \mathrm{kyr})$ during the initial phases of deposition promoted onlap of the detachment forelimb. The progressively rotated bedding surfaces of the upper $65 \%$ of unit 2 and the geometry of their contacts define the growth of the detachment fold and related erosion and deposition. They demonstrate that during a 1-m.y.-long interval, the fold's forelimb progressively steepened and overturned in response to continued shortening. As the anticline grew, its crestal area and those pregrowth strata on its backlimb (i.e., all strata that were not mantled by syntectonic sediments) were subjected to erosion. 


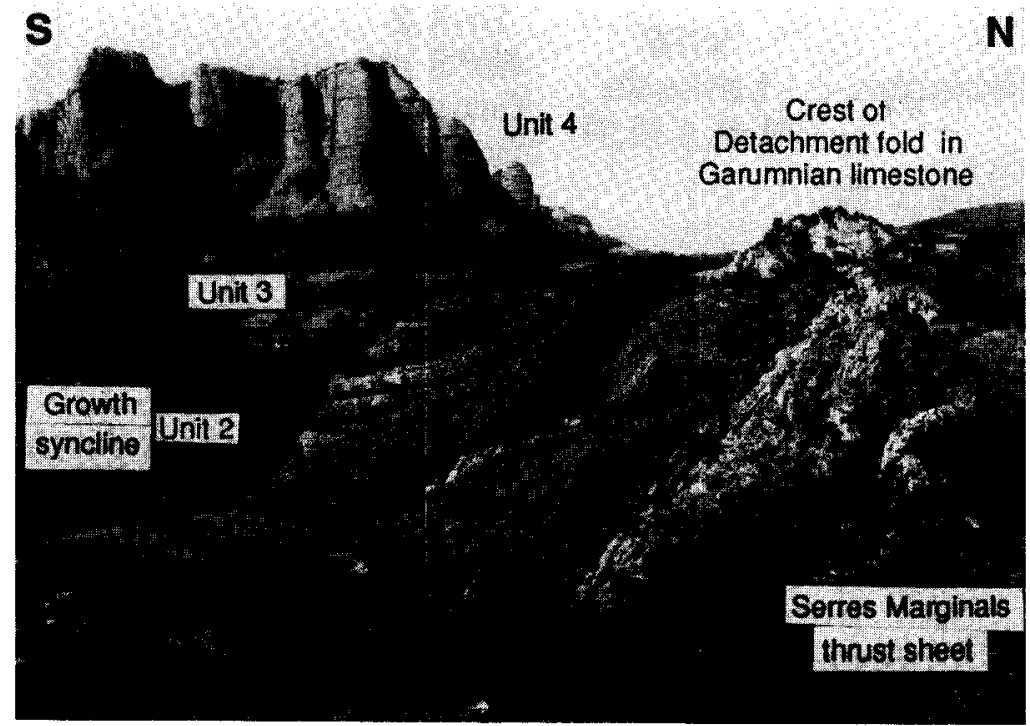

Figure 6. Overview of the upper $100 \mathrm{~m}$ of unit 2 in the growth syncline and the overlying conglomerates of units 3 and 4. Progressive tapering and steepening of each stratigraphic packet in unit 2 delineates the growth syncline adjacent to the folded forelimb of Garumnian limestones (visible on the right skyline).

Along the length of the detachment fold for a strike distance of 1-2 km, variable amounts of erosion have resulted in contrasting contact relationships with unit 2 . In regions where the Garumnian limestones were not successfully breached, the oldest syntectonic strata rest upon these limestones in the forelimb of the fold and have been overturned along with this limb (Figures 6 and 7 , profile $\left.A-A^{\prime}\right)$. In areas where erosion incised through the fold crest (Figure 7, profile B-B'), an angular unconformity occurs within unit 2 . The conglomerates above the unconformity are not overturned, but they display a very pronounced angular discordance with the pregrowth strata (Figure 7, profile B-B'). We interpret the unconformity surface to represent a continuation of the erosional surface defining the base of the paleovalley to the north. Breaching of the detachment fold does not appear to have been controlled by obvious weaknesses in the exposed preEocene strata. Alignment of the breached anticline with a paleovalley oriented at a high angle to the fold crest (Figure 3 ) suggests that greater erosion was associated with concentrated flow along this transverse valley. Thus despite the overall importance of longitudinal transport and deposition, higher gradient transverse drainage systems and their erosive capabilities can strongly influence geometries within the syntectonic strata.

Contrasting erosional and depositional histories are associated with unbreached versus breached portions of the detachment fold. Where the crest is unbreached, the well-exposed, upper $100 \mathrm{~m}$ of syntectonic strata (Figure 6) appear to be continuously deformed and display similar tapers and angular relationships among successive conglomeratic beds (Figure 7A). In contrast, erosional breaching of the resistant limestones forming the crest and forelimb of the anticline permits accelerated erosion of the fold's core and subsequent lowering of the depositional surface. This results in a truncation of both the pregrowth and syngrowth strata in the midst of the main phase of anticlinal growth, creating two wedges of fanning growth strata that are superposed along an angular discordance within the growth syncline. The younger wedge is inset farther toward the hinterland (Figure 7B).

Paleovalley deposits. Two paleovalleys were incised at high angles to the crest of the detachment fold and stretched from there to the Montsec thrust sheet (Figures 3,9, and 10). The position of these valleys is strongly correlated with local structure, whereby high points on the former landscape correspond with resistant pregrowth strata, and paleovalleys form in weaker beds and along hanging wall synclines. Minimum depths of the paleovalleys can be measured directly from the presently preserved fill within the valleys and by the geometry of the valley margins. The relative topographic position of each paleovalley and stratigraphic positions with their fills can be estimated through comparison to a common reference level: in

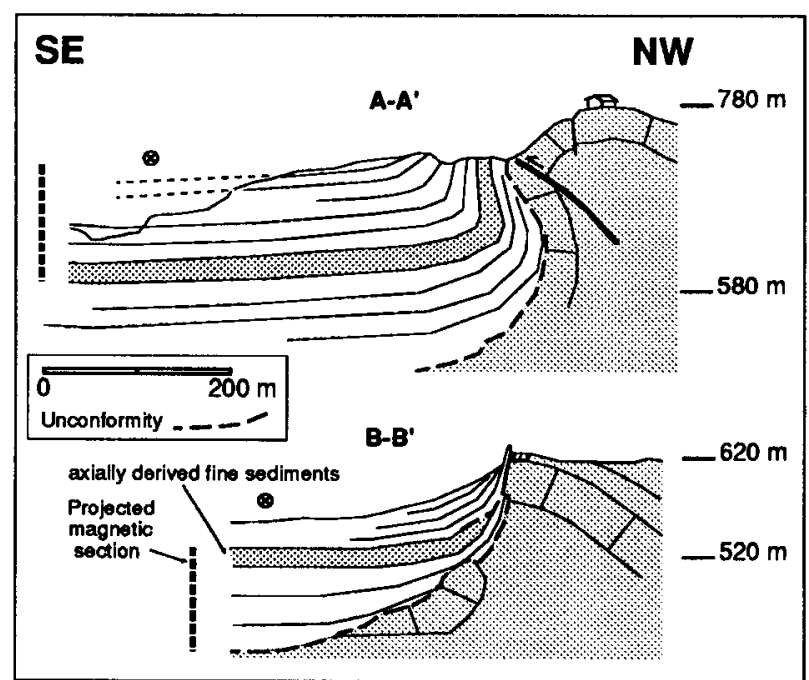

Figure 7. Simplified cross sections of unit 2 in the growth syncline. The location of the magnetic section is projected into the plane of sections. Following early onlap of syntectonic conglomerates on preexisting and slowly deforming footwall topography, continuous folding of the unbreached anticline led to an overturned, wedge-shaped progressive unconformity (A-A'). Erosional breaching of the detachment fold (B-B') along the trend of the major hanging wall paleovalley causes truncation of the older onlapping, progressively folded conglomerates. See Figure 3 for section locations. 


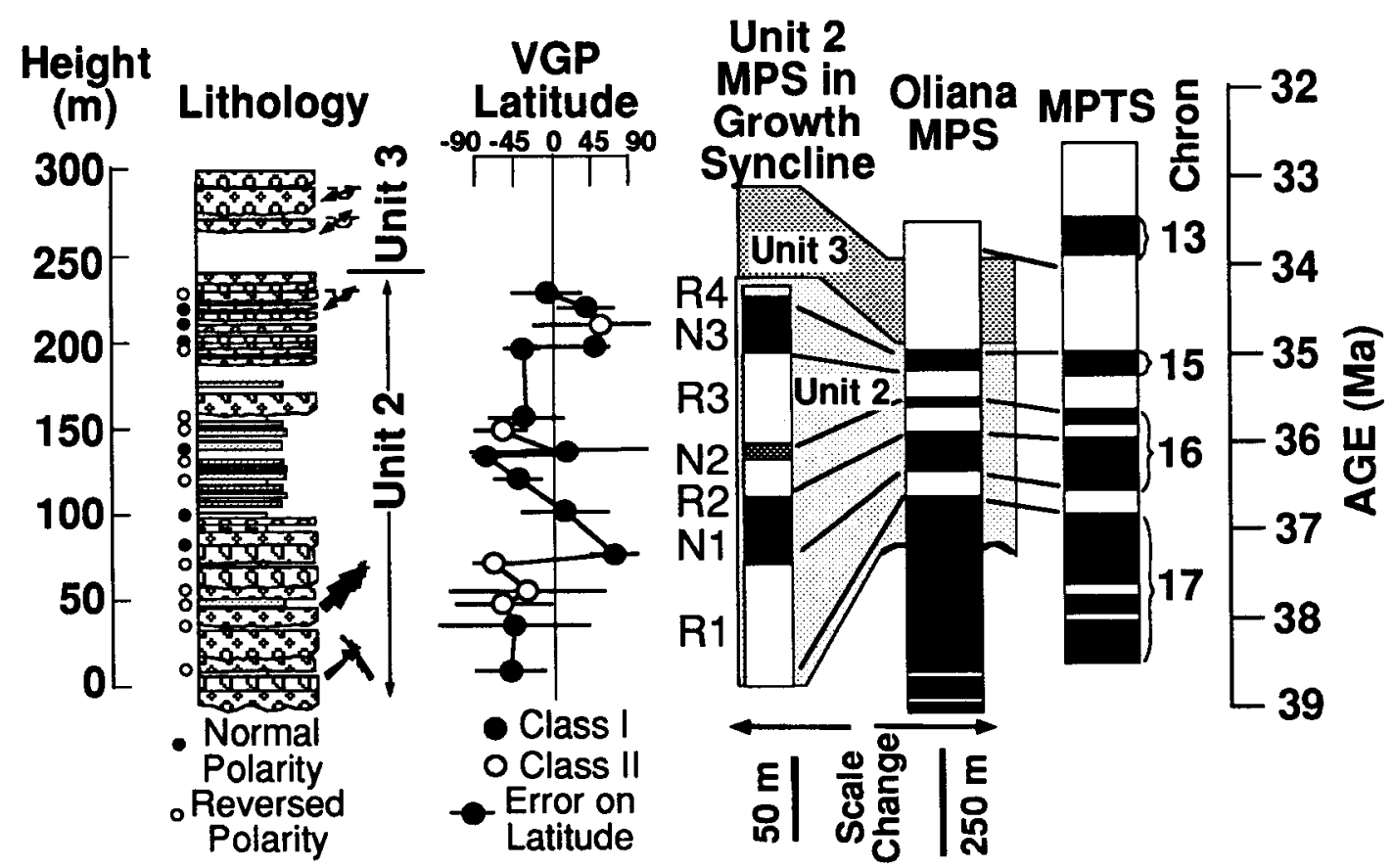

Figure 8. Lithostratigraphy, paleocurrents, magnetic polarity stratigraphy (MPS), and correlation for unit 2 in the growth syncline. Paleoflow was dominantly to the SW. Two magnetozones (in gray) are only defined by single class I sites. Correlation of the MPS from unit 2 with the Oliana MPS from the southeast flank of the Oliana anticline [from Burbank et al., 1992] and with the magnetic time scale [Cande and Kent, 1992] is shown. Shaded areas represent the stratigraphic range on units 2 and 3.

this case, the base of the overlying conglomerate (unit 3 ) which was deposited across all of the outcrops of unit 2 in the study area.

The smaller paleovalley was incised $\sim 50 \mathrm{~m}$ into a syncline cored by lower Eocene sandstones. Both margins of the $\sim 1.3-\mathrm{km}$-wide paleovalley are defined by fins of resistant freshwater Paleocene limestone (Figures 3, 9, and 10). In fact these formed topographic barriers on the landscape that generally confined the fluvial system within the paleovalley. A major paleovalley was situated immediately to the east of the minor one (Figure 3 ) and is divided from it by one of the limestone fins (Figures 9 and 10). Cut into Paleocene siltstones and floored by additional beds of resistant limestones, the valley is at least $1 \mathrm{~km}$ wide and is $\sim 140 \mathrm{~m}$ deep. The western valley wall is vegetated and poorly exposed, and the eastern limit of the paleovalley has been removed by erosion.

Flow indicators in the valley fill (see below) and the spatial alignment of the major paleovalley with the breached crest of the detachment fold define the $\sim \mathrm{N}-\mathrm{S}$ trend of the paleovalley across the backlimb of the detachment fold (Figure 3). Given the geometrical necessity that the paleovalleys were connected with the

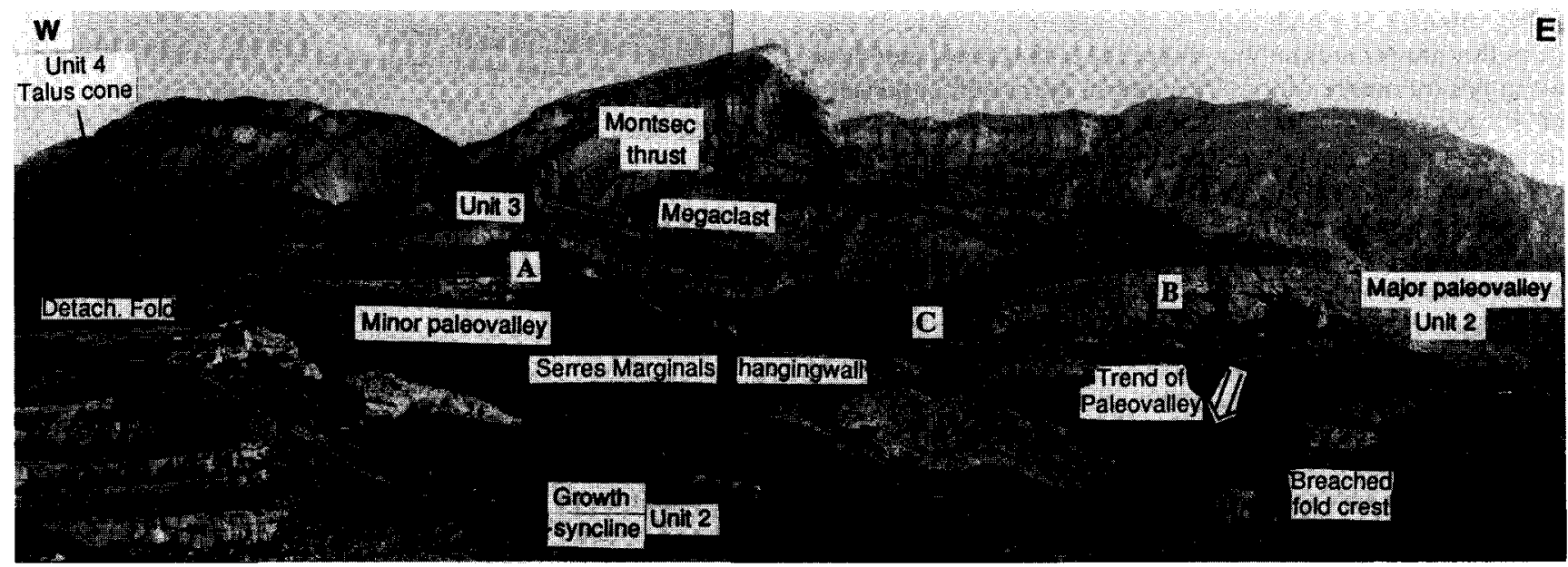

Figure 9a. Overview to the north of the major (right) and minor (left) paleovalleys in unit 2 with the locations of sections A, B, and C shown. The folded strata of unit 3 and the megaclast of Cretaceous limestone overlie unit 2 and are strongly folded by the Montsec overthrust. A small, nonthrusted remnant of unit 4 is visible on the left, where it overlies the Montsec thrust. In the foreground, Garumnian limestones at the crest of the Serres Marginals anticline bound the growth syncline (folded strata visible in lower left). 


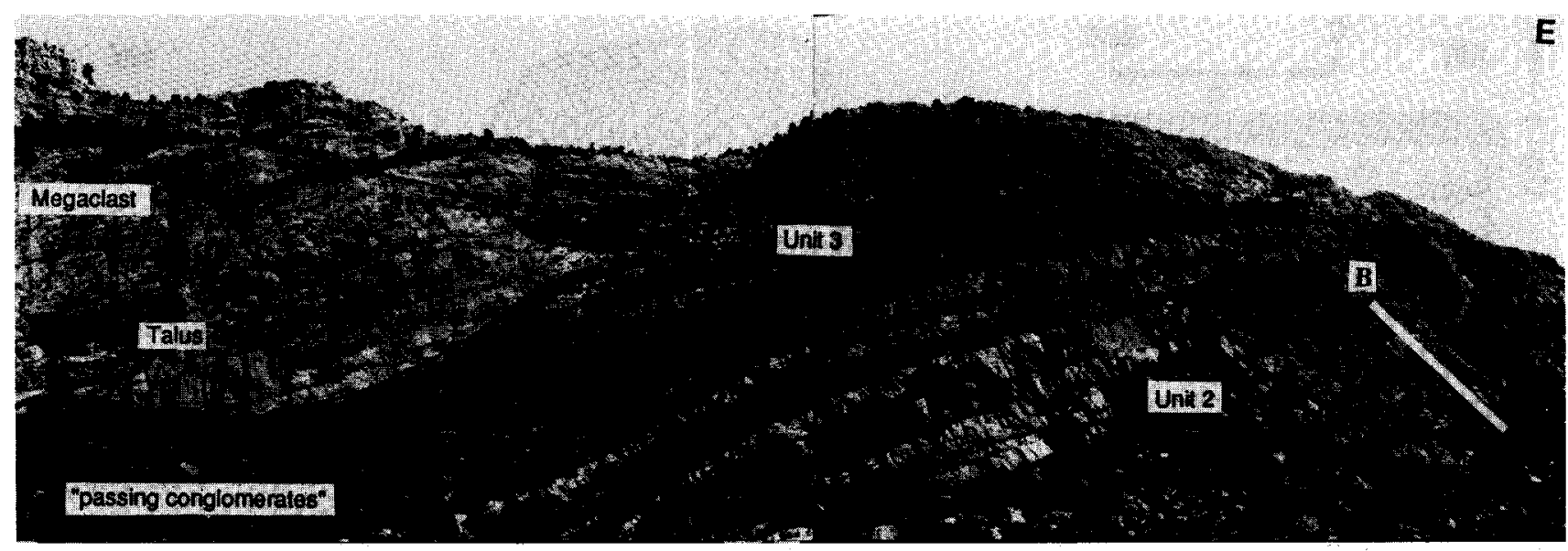

Figure 9b. Rapid lateral facies changes in the major paleovalley are displayed by the abrupt thinning and fining toward the southwest of the conglomerate beds. In contrast, the "passing conglomerate" and the overlying basal coarse-grained bed of unit 3 taper toward the northeast, probably due to syndepositional uplift along the Montsec thrust. Location of section B (Figure 10) is shown. A cone of talus breccia occurs along the flank of the Cretaceous megaclast on the left.

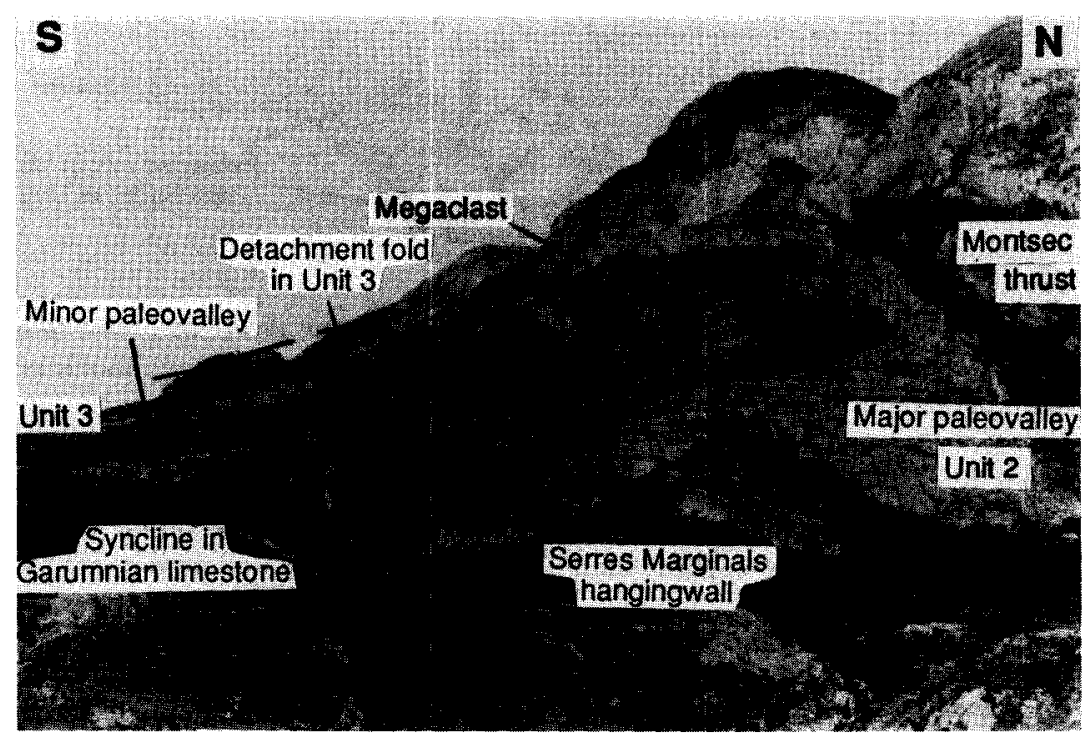

Figure 9c. View parallel to the structural front (to the $S W$ ) that emphasizes the role of the resistant Garumnian limestones in defining the geometry of the minor paleovalley; the detachment fold in the basal beds of unit 3 above less deformed strata of unit 2; and the strongly overturned footwall syncline containing units 2 and 3 beneath the Montsec thrust.

growth syncline, we use the magnetic chronology of unit 2 in the growth syncline and the age and relative stratigraphic position of the unit 2 - unit 3 boundary to estimate the ages of the undated paleovalley fills. Thus the strata in the major and minor paleovalleys are estimated to range from $\sim 36.0-35.0 \mathrm{Ma}$ and $\sim 35.3$ 35.0 Ma, respectively.

Minor paleovalley sedimentology: The strata of unit 2 within the smaller paleovalley are generally tabular bodies, but their sedimentology contrasts with that of the coeval conglomerates in the growth syncline. No clasts of Axial Zone origin were recognized within the paleovalley, and all of the rock types present are also found in nearby thrust sheets. On the basis of imbrications, gutters, grooves, and cross beds, paleocurrents in the lowest, most topographically constrained part of the fill display eastwards flow directions (Figures 10 and 11), whereas higher up in the fill, paleocurrents appear to swing to the south. In the lower parts of overlying unit $3, \sim 25 \mathrm{~m}$ stratigraphically higher, paleocurrent directions are to the SW, and clasts of Axial Zone rock types are common.

The lower $15 \mathrm{~m}$ of the fill are characterized by $0.2-$ to $2-\mathrm{m}$ thick beds of subangular to subrounded pebble-to-boulder conglomerates displaying planar, abrupt contacts between depositional units (Figure 11a). Clasts are commonly $>10 \mathrm{~cm}$ in diameter, and some boulders of $\sim 1-\mathrm{m}$ diameter are present. Although many of the beds are matrix-rich and inversely graded (at least in their lower parts), they are also clast supported. The 


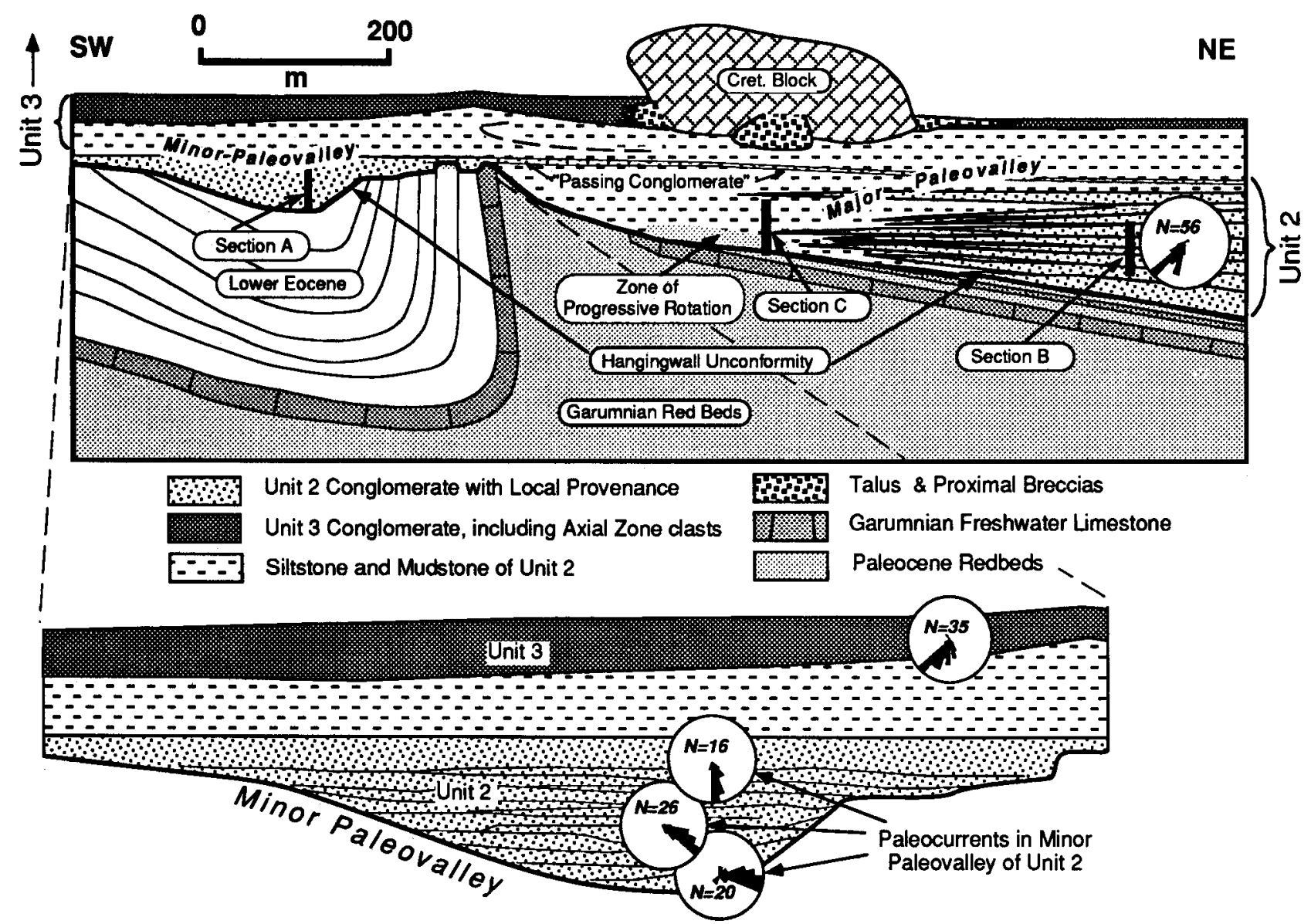

Figure 10. Topography, schematic stratigraphic geometries, paleocurrent directions, clast source areas, and section locations for units 2 and 3 in the major and minor paleovalleys. Section is approximately perpendicular to the orientation of the paleovalleys. See Figure 3 for location.

middle and lower parts of many units lack internal structure and are disorganized, whereas the tops of several units show consistent clast imbrications.

The upper half of the paleovalley fill is characterized by more channelized beds with scours and grooves up to $50 \mathrm{~cm}$ deep along their bases (Figure 11a). Most beds are $20-40 \mathrm{~cm}$ thick and rarely exceed $1 \mathrm{~m}$. Internal structure, including parallel and planar cross bedding, is common, especially in the sandier units. Conglomeratic beds are supported by subangular to subrounded clasts, and both conglomerates and sandstones typically fine upward. The topmost conglomerate beds overtop the confining limestone fin to the east and spread laterally into the large paleovalley to the east (Figure 10).

The matrix-rich and coarsening upward character of the early deposits of the minor paleovalley fill are interpreted as representing hyperconcentrated flows [Smith, 1988] and noncohesive mass flows [Nemec and Steel, 1984]. Subangular clasts of local rock types suggest that these flows were transported only short distances from nearby hanging walls. These early flows were funneled eastward within the confined margins of the paleovalley. The consistent imbrications found on the upper surfaces of some flows suggest that they were fluvially reworked. As the valley broadened upward, fluvial deposition from shallow rivers became more common, and flow directions rotated toward the south, i.e., transverse to the structural grain (Figures 10 and 11a).
Geometrical relationships: Prior to the initiation of filling, the paleovalley was $\sim 50 \mathrm{~m}$ deep and $1 \mathrm{~km}$ wide. The strata of unit 2 within the minor valley passively onlap the beveled lower Eocene strata. This eroded surface displays a steplike geometry with inclined treads up to $100 \mathrm{~m}$ wide and risers of 5-15 m that correspond either with lithological breaks or with abrupt changes in bedding attitudes in the pregrowth strata. Dips of the strata within the paleovalley fill are shallow and uniform, suggesting little syndepositional tilting.

Major paleovalley sedimentology: The major paleovalley is situated adjacent to and east of the minor paleovalley (Figures 3, 9 , and 10 ). In contrast to the laterally consistent strata of the minor valley, the infilling of the major valley is characterized by marked lateral changes in both facies and sediment-accumulation rates across short distances. The facies changes are clearly visible in outcrop, where across a lateral distance of $\sim 400 \mathrm{~m}$, there is a rapid fining in grain size from nearly continuous conglomerates to $>70 \%$ medium grained sandstones and siltstones (Figure 9). Two sections were measured in the valley fill: one in coarsegrained strata the center of the valley and the other in much finergrained strata near the eastern valley wall.

The strata in the valley center (Figures 10 and 11b) are dominated by amalgamated, clast-supported conglomerates with typical bed thickness of $\sim 50 \mathrm{~cm}$. Less than $5 \%$ of the beds have mean grain sizes smaller than $2-5 \mathrm{~mm}$. The conglomerates are poorly sorted, have undulatory to moderately scoured bases, and com- 


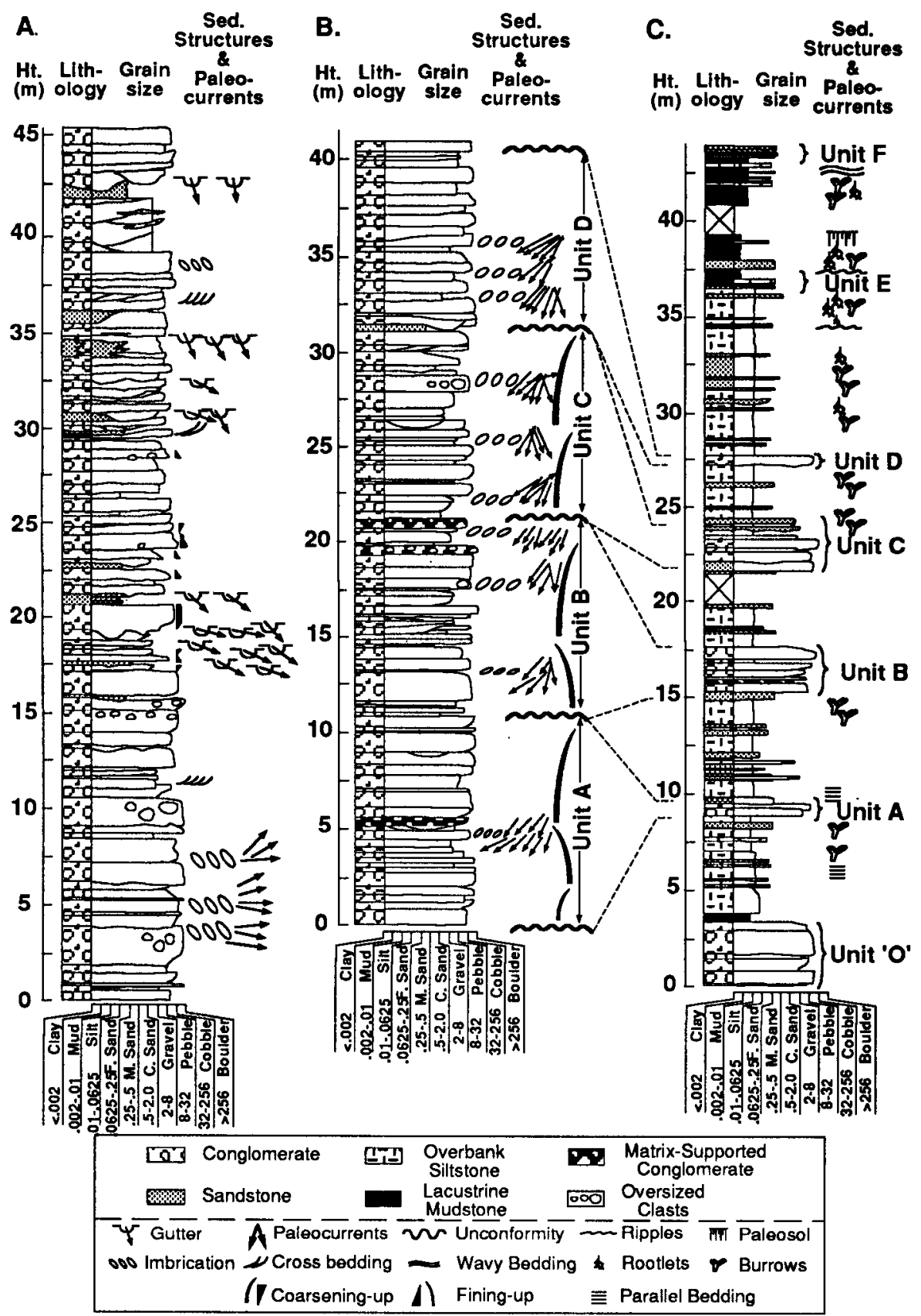

Figure 11. Stratigraphic columns of unit 2 in the minor and major paleovalleys. (See Figure 10 for locations.) (a) Stratigraphy of small paleovalley. Note upward rotation of paleocurrents from east to south. (b) Stratigraphy of the central part of the major paleovalley. (c) Stratigraphy of the marginal facies of the major paleovalley. Labeled coarse-grained units can be correlated to stratal groupings in the central valley and display rapid thinning toward the valley margin.

prise subangular to subrounded clasts of local rock types. Although some beds coarsen or fine upward, most of them are ungraded. A few beds are matrix-rich and disorganized. Cross bedding at scales of $10-100 \mathrm{~cm}$ is present in some pebbly units, and consistent clast imbrications are found in many beds, in part due to the presence of many discoidal clasts. Clusters of large $(\sim 50 \mathrm{~cm}$ in diameter) boulders form the centers of lobate depositional units that display low-angle cross beds dipping away from the central boulders. At the panoramic scale, distinctive horizontal breaks are visible within the vertical succession of conglomerates and can be traced laterally into fine grained units (Figure
9). At the detailed outcrop scale, these breaks are defined by finer grained conglomerates that are used to delineate boundaries between major depositional units (Figure 11b).

The laterally equivalent strata near the western valley wall display a sharply contrasting character. These beds (Figures 10 and 11c) are predominantly siltstone, fine-to-medium sandstone, and mudstone. Conglomerates occur as thin packets of individual or amalgamated beds, and each grouping of conglomerates can be traced laterally to coeval thicker and coarser units in the valley center. Calcareous paleosols are commonly present, and burrowing and root traces are almost ubiquitous in the massive, fine 
grained units. A small proportion of the siltstones are laminated, and thin $(15 \mathrm{~cm})$ arenaceous limestones occur several times in the upper part of the section.

The topmost part of the valley fill below the base of unit 3 is a 20 - to 25 -m-thick succession of thin $(<40 \mathrm{~cm})$ sandstones $(20 \%$ of total thickness) and yellow-orange and pink siltstones. These strata are extensively mottled and burrowed, and they contain abundant rootlets and pedogenically altered sandstones. This fine-grained sequence drapes across the top of both paleovalleys and may also correspond with a zone lacking outcrops at the unit $2 / 3$ boundary in the growth syncline.

The sedimentological data indicate an alluvial fan of local origin filled the medial part of the major paleovalley. Persistent imbrications, low-matrix content, large lateral extent of beds, and limited stratal thicknesses suggest that deposition occurred from unconfined fluvial flows, some of which are likely to have been hyperconcentrated [Smith, 1988]. The boulder clusters are interpreted as bar cores around which low-angle accretion occurred as the bar expanded [Hein, 1984].

Along the western valley margin, the fine-grained nature of the strata, abundant bioturbation and soil development, and occasional thin limestones suggest relatively slow deposition on a low-gradient floodplain. Rapidly thinning conglomeratic units, 1$3 \mathrm{~m}$ thick, encroached into this marginal environment infrequently.

Given the close proximity of these two sections $(\sim 400 \mathrm{~m})$, the abrupt facies changes between them indicate that the lateral margin of an alluvial fan is preserved here (Figures 9 and 10). Highly energetic depositional environments are present in the valley center, whereas ponded and tranquil deposition characterizes the region between the fan and the valley wall.

The extensive paleosol-dominated succession that caps unit 2 suggests that an interval of quiescence prevailed prior to the initiation of deposition of unit 3 . The absence of conglomerates further suggests that the drainage system was being reorganized, possibly in response to the initial transfer of thrust deformation to the more hindward Montsec thrust.

Geometrical relationships: Near the western margin of the major paleovalley, the basal strata of unit 2 have been rotated during deposition. Over a stratigraphic span of $20 \mathrm{~m}$, bedding dips decrease from vertical to $\sim 55^{\circ}$ to the NW. These beds were deposited coevally with some of the syntectonic strata in the forelimb of the growing detachment fold. The rotated beds can be interpreted as a wedge-shaped "progressive unconformity" [Riba, 1976] that opens toward the hinterland. This back-tilting is interpreted to result from flexural slip folding during tightening of the syncline in the pre-Eocene strata which underlie the margin of the major paleovalley. Uniform dips of beds above the rotated strata suggest that differential folding slowed or ended midway through the filling of the paleovalley.

Given that the paleovalley represents at least $150 \mathrm{~m}$ of incision near the trace of the Montsec thrust, it is not surprising that considerable erosion also occurred across the crest of the growing detachment fold where traversed by the paleovalley. During this incision, uplift of the core of the detachment fold was apparently too rapid to permit permanent accumulation of syntectonic strata within the paleovalley.

Because individual strata and groupings of strata can be physically traced from the paleovalley's western margin toward its center, it is possible to compare lateral changes in stratigraphic thicknesses and apparent sediment-accumulation rates. Four reference horizons serve to delineate these rate changes: the base of the paleovalley; the base of "unit A"; the top of "unit F", and the conglomerate (the "passing conglomerate"; Figures 9B and 10) that crosses the top of the minor paleovalley and can be traced toward the center of the major paleovalley. Comparison of these markers shows that there was a clear-cut shift of the zone of rapid accumulation from the valley center toward its margin. Below unit A, a much greater thickness of strata accumulated in the central part of the paleovalley. Part of this is simply due to passive infilling of an eroded landscape. Traceable beds which thin toward the valley margin, however, indicate that there was also greater subsidence in the valley center. This trend continues up through unit $F$, during which time there is $2-3$ times more accumulation in the valley center than near its western margin (Figures 10 and 11). This interval coincides with the previously described progressive rotation of the basal strata along the valley wall, such that the contrasts in accumulation probably result from differential uplift of the valley wall during folding of the Serres Marginales hanging wall.

Neither the observed $7^{\circ}$ taper that results from thinning of groups of beds nor the rapid change from a tabular bed geometry in the valley center to a strongly tapering one toward the margin are consistent with the expected bedding geometry and topographic shape of an unperturbed alluvial fan [Wallace, 1978; West, 1991]. It therefore appears that folding at this scale can have dramatic effects on sediment accumulation across short $(\sim 400 \mathrm{~m})$ distances and that differential subsidence confined the fan to the valley center during the early part of the valley filling.

Between unit $\mathrm{F}$ and the "passing conglomerate", the opposite accumulation trend prevails: there is more accumulation toward the valley margin than in its center (Figure 10). In the lower part of this sequence, there appear to be nearly equal accumulation rates, but in the later stages during predominantly finer grained deposition, the valley-margin rates appear to be 2-4 times greater than in the center. This suggests that, during the later stages of unit 2 deposition, deformation was shifting to a more hindward location, i.e., the Montsec thrust [Burbank et al., 1992], and beginning to deform the proximal part of the basin adjacent to the thrust.

\section{Unit 3}

Unit 3 in the study area was deposited above unit 2 from the north limb of the Oliana anticline to the trace of the Montsec thrust. It also covers with little deformation the crest of the detachment fold. Deposition of unit 3 appears to coincide with motion on the Montsec thrust, which placed unit 3 in a footwall position with respect to the active thrust. The depositional and deformational history of unit 3 and its contrasts with the underlying units are influenced by its structural position and the way in which deformation was propagated through the footwall.

Sedimentology. Most of the exposures of unit 3 occur in steep, mostly inaccessible cliffs for which we have no detailed sedimentology. Nonetheless, some striking contrasts with unit 2 are apparent. Most importantly, rather than deriving solely from local source areas, the conglomerate clasts indicate significant derivation from the Axial Zone. The inference that these should then belong to longitudinally flowing rivers is borne out by paleocurrents in the basal parts of unit 3 (Figure 10) which clearly show transport to the SW, parallel to the structural front. Thus, in contrast to the sloping transverse surfaces in the paleovalleys of unit 2, the depositional surface of this unit should be essentially horizontal in sections transverse to structural front. The conglomerates of unit 3 are clast-supported, display broad bedding (1-3 $\mathrm{m})$, and contain uncommon, but well-bedded, fine 
sandstone interbeds. The clasts of unit 3 are generally rounded to subrounded, suggesting they are farther traveled than most of the clasts in the proximal paleovalleys of unit 2 . In areas close to the Montsec thrust, the successions of conglomerates and intervening fine-grained siltstones in unit 3 display more tabular geometries and cover broader areas than do the underlying strata within the paleovalleys. The total stratigraphic thickness of unit 3 thins southward toward the Oliana anticline, and the generally even proportions of very coarse- and fine-grained depositional units in proximal areas are replaced by increasingly dominant cor:glomeratic strata toward the south.

One remarkable aspect of unit 3 is the incorporation of a megaclast of Cretaceous limestone (Figure 9). This very large block ( $\sim 350 \mathrm{~m}$ long and $>100 \mathrm{~m}$ thick) apparently slid from the hanging wall to the footwall of the Montsec thrust. The base of this megaclast is not exposed, but abutting its margins are cones of unsorted, angular clasts of locally derived monolithologic breccias that are incorporated into ill-defined beds dipping steeply away from the block. At higher stratigraphic levels, the megaclast is onlapped and overtopped by tabular units of conglomerates and siltstones that display no significant thickness changes as they approach the depositional contact with the block.

Because it occurs near the base of unit 3 at a time when renewed motion on the Montsec thrust was just beginning [Burbank et al., 1992], it appears likely that prior to this latest phase of deformation, there were at least several hundred meters of residual topography on the Montsec hanging wall as a result of middle and early Eocene motion on this thrust [Vergés and Muñoz, 1990]. Around the megaclast's margins, talus cones developed, and later, both these cones and the megaclast were passively enveloped by the aggrading beds of unit 3 .

Age. Unit 3 has not been directly dated in the study area. Magnetic dating of related strata on the southeastern limb of the Oliana anticline [Burbank et al., 1992], in combination with the new age limits placed on unit 2 (Figure 8), indicates that unit 3 ranges in age from $\sim 35.0$ to $\sim 34.0 \mathrm{Ma}$. On the southeast limb of the Oliana anticline, $250-300 \mathrm{~m}$ accumulated during this interval at a mean rate of $\sim 25-30 \mathrm{~cm} / \mathrm{kyr}$. Only $\sim 150 \mathrm{~m}$ of unit 3 are preserved in the present study area to the northwest of the anticline. This yields a mean rate of $\sim 15 \mathrm{~cm} / \mathrm{kyr}$, which is essentially unchanged from the mean rate of accumulation of unit 2 .

Geometrical relationships. At the large cross-sectional scale, the thinning and onlap of unit 3 southward on to the north flank Oliana anticline (Figure 3) clearly indicate this large anticline was still growing at this time. In proximal areas adjacent to the Montsec thrust, the strata of unit 3 have been strongly folded (Figure 9) into a footwall syncline. Small thrust faults occur along some of the contacts between the megaclast and adjacent conglomerate beds. During folding, the rheological contrasts between the megaclast and the surrounding strata probably caused the more rigid block to glide along minor out-of-syncline thrusts. On the north side of the megaclast, strata of unit 3 are steeply dipping and display a fanning geometry ranging at present from dips of $20^{\circ}$ overturned to north to dips of $65^{\circ}$ to the south. This syndepositional wedge-shaped geometry in unit 3 is interpreted to result from folding and uplift of the Montsec footwall. Gentle warping of unit 3 as it passes over the crest of the detachment fold suggests that this anticline and the hanging wall syncline to its north (Figures 2 and 4 ) continued to tighten in response to Montsec thrusting.

Directly above the limestone fin that defines the eastern margin of the minor paleovalley (Figure 9a and 9c), the basal conglomeratic strata of unit 3 are folded into an anticline. It appears that the strata of these beds thicken on each flank of the anticline and thin over its crest, whereas the underlying siltstones and paleosols clearly thicken along the fold axis. Significantly, the underlying "passing conglomerate" at the top of unit 2 is not similarly folded (Figure 10). This discordant folding suggests that during the early stages of Montsec thrusting, a localized detachment propagated at very shallow depths within the finegrained units, and a detachment fold of small amplitude $(\sim 15 \mathrm{~m})$ developed above it.

\section{Unit 4}

Unit 4 overlies unit 3 throughout the study area and is preserved in steep cliffs that are generally inaccessible. On all sides of the Oliana anticline, unit 4 is extensively preserved and represents the last major depositional event in this region. The magnetic data [Burbank et al., 1992] indicate that initial deposition of unit 4 began at $\sim 34.0 \mathrm{Ma}$. When sedimentaccumulation rates from the underlying strata are extrapolated to the top of this unit, they suggest that it may span 3-4 m.y. [Vergés and Burbank, 1994].

Sedimentology. This unit contains abundant clasts that were derived from the Axial Zone and consists almost entirely of clastsupported, rounded, and often well-imbricated conglomerates. Most of the coarse-grained depositional units are 1-3 m thick and display a normally graded to ungraded character. In contrast to the underlying units, there are very few fine-grained intervals preserved within unit $4(\leq 5 \%)$. Where there are thin units of intervening siltstones, however, long gutters are very common in the base of the overlying conglomerates. In combination with clast imbrications, these gutters provide unambiguous paleoflow directions toward the $S W$. Therefore unit 4 was deposited from rivers flowing parallel to the structural grain and carrying fartraveled clasts into the foreland.

Where unit 4 is preserved directly adjacent to the Montsec hanging wall, small, steeply inclined cones of breccia abut the lower part of the Montsec escarpment. There is no evidence that unit 4 overtopped the Montsec hanging wall in this transect. In fact, the topographic relief on the Montsec hanging wall was much greater than the thickness of unit 4 , which was represented by a steep apron of talus breccias banked against the lower slopes of the hanging wall. Although the total amount of topography inherited from middle and early Eocene deformation is unknown, it is likely to represent about half of the present relief, given the limited amount of late Eocene Montsec shortening [Vergés and Burbank, 1994].

Geometrical relationships. Because it is the stratigraphically and topographically highest syntectonic unit, unit 4 is more dissected than the older depositional units, and its complete geometry is more difficult to describe. Nonetheless, its proximal strata are only very slightly deformed by the Montsec thrust which gently folds them in several places. This absence of strong deformation indicates that major motion on the Montsec had terminated when deposition of unit 4 commenced.

Unit 4 thickens away from the Montsec hanging wall toward the south and SE (Figure 2) and then thins as it approaches the backlimb of the Oliana anticline. Our tectonic reconstructions suggest that most of the thrusting and folding within the anticline itself ceased at this time [Burbank et al., 1992]. Nonetheless, the thinning of unit 4 adjacent to the Oliana anticline indicates that some topography persisted across its structural crest, where today erosion of the weakly resistant marls in the core of the fold have caused a strong topographic inversion. 


\section{Discussion}

The growth of the Oliana anticline and the coeval deformation of structures related to the Serres Marginals and Montsec thrust sheets represent the fundamental tectonic controls on both deposition and topography in the study area. Today, the Segre River cuts directly through the structurally highest part of the Oliana anticline. During deformation, however, this structure presented an oblique barrier to flow of the ancestral Segre River and caused it to divert to either flank of the growing fold (Figure 12). Along the southeastern limb of the Oliana anticline, low topography persisted southwards into the undeformed foreland, and paleocurrent indicators [Burbank et al., 1992] suggest a fanning of flow directions once the river passed the northeastern nose of the anticline, which controlled the entry point of the river into the foreland. On the northwestern limb of the anticline where we have focused the present study, the ancestral Segre was channeled along the southwest trending structural moat, represented by an irregular synform between the Montsec hanging wall highlands and the Oliana anticline (Figure 2).

The progressively fanning dips and the tapered geometry of strata within the growth syncline of unit 2 provide clear evidence of syndepositional rotation of the forelimb of a growing detachment fold. During early stages of deposition and fold growth, rapid accumulation primarily promoted onlap of inherited topography. The rates of vertical uplift are interpreted to have been slower than the accumulation rates $(\sim 25 \mathrm{~cm} / \mathrm{kyr})$ at this stage. During the succeeding stage of deposition (36.4-35.7 Ma), accumulation rates in the growth syncline were slow $(\sim 6 \mathrm{~cm} / \mathrm{kyr})$, finer grained strata were deposited, and the paleovalleys attained their maximum depths as they incised across the crest of the detachment fold. Aggradation in the growth syncline accelerated to $\sim 14 \mathrm{~cm} / \mathrm{kyr}$ between 35.7 and $35.0 \mathrm{Ma}$. Continuous tapering of strata toward the syncline's margin, combined with the absence of clear evidence for either strong overlap or offlap with respect to the fold crest, suggests that vertical rates of flank uplift and fluvial deposition were nearly equivalent along the forelimb of the detachment fold. Thus during deposition of unit 2, the longitudinally flowing river was confined between the Oliana anticline and the detachment fold. Despite the ongoing uplift at rates of $0.1-0.3 \mathrm{~mm} / \mathrm{yr}$ in the folds defining the margins of this trough, no significant topography was created within the depositional plain.

The positioning of the paleovalleys provides insights on the roles played by lithology and structure in controlling incision, whereas the infilling of the paleovalley reveals aspects of the topography, deformation, and source areas in the Serres Marginals hanging wall. Not unexpectedly, folding and uplift of variably resistant bedrock strata lead to accentuated erosion of weaker beds. The minor paleovalley is enclosed by a resistant limestone and is localized along the axis of a sandstone- and marl-cored fold. These same resistant limestones also delineate the highest preserved point along the only preserved margin of the major paleovalley, which is incised into less resistant red beds.

The paleovalleys represent the only significant transverse elements in the evolving landscape that are still preserved. These valleys are oriented perpendicular to the structural trend and served as conduits carrying locally derived detritus to the longitudinally oriented, larger river (section B-B", Figure 2). The volumetrically small contribution ( $<10 \%$; Figures 2,3 , and 4 ) of the infilled transverse valleys to the total fill represented by units 2-4 indicates the clear dominance of deposition from the axial
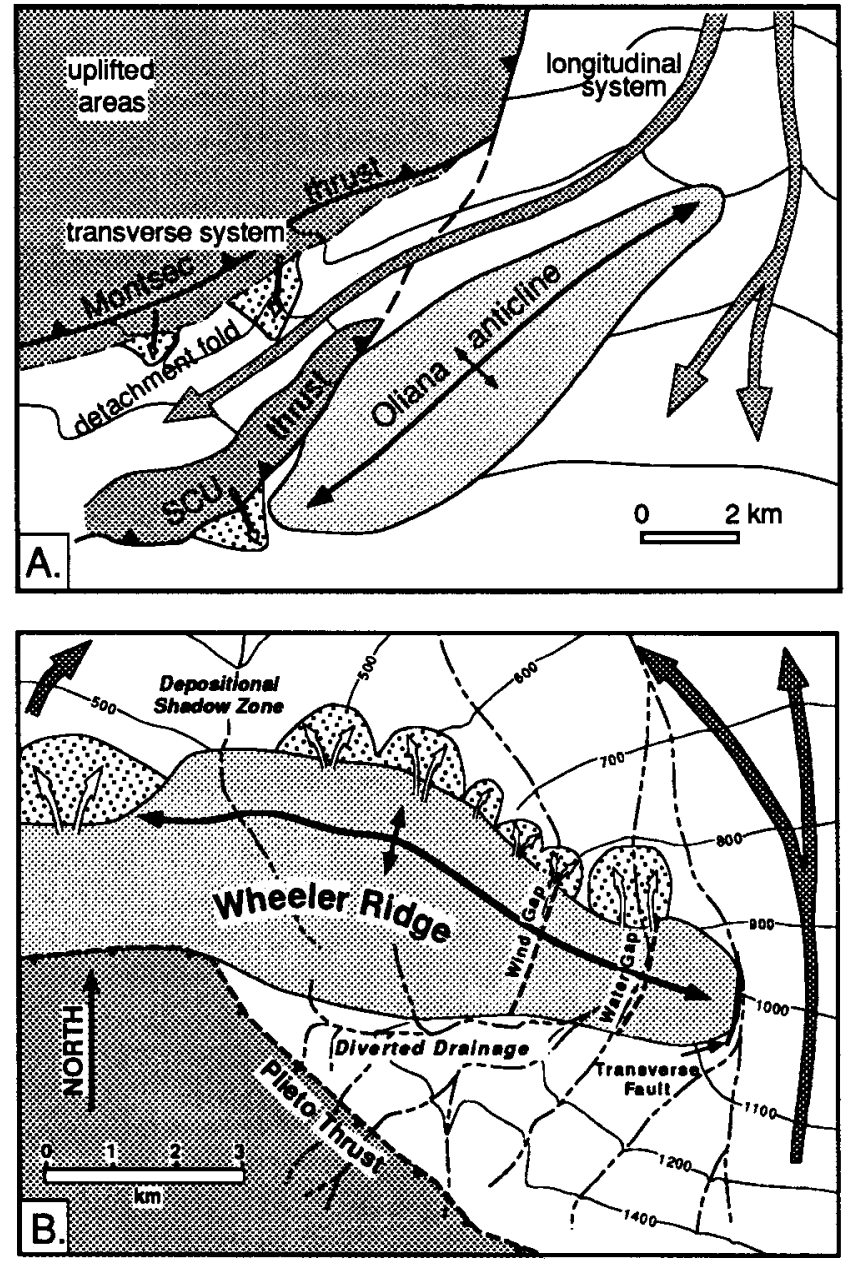

Figure 12. Comparison of the major structural and depositional elements in the vicinity (a) of the Oliana anticline and (b) of Wheeler Ridge, southern California. The absence of a major river at Wheeler Ridge, combined with more rapid uplift of the anticline and impinging thrusts, control the large-scale differences in the depositional geometries between these sites. The transverse valleys and smaller-scale drainage patterns at Wheeler Ridge provide reasonable analogs for the paleovalleys in Serres Marginals anticline.

river. It appears that detrital sediment production from the small, steeply inclined, and largely limestone-dominated local catchments was overwhelmed by the contributions of the axial rivers.

The incision of the larger transverse paleovalley through the crest of the growing Serres Marginals anticline caused a locally important unconformity to be generated within unit 2 in the growth syncline. This resulted in recognizable along-strike variations in the geometric relationship between syntectonic strata and the folded pre-Eocene strata. The deeper incision that occurred along the major paleovalley caused juxtaposition of unit 2 with eroded limestone in the backlimb of the fold (section B-B', Figure 7), rather than overlapping the forelimb, as is seen farther to the west (section A-A', Figure 7).

The switch from incision to deposition along the paleovalleys occurred while the detachment fold was growing and the strata of unit 2 were filling the growth syncline. We assume that because the transverse valleys were tributaries to longitudinal river in the growth syncline (Figures 2 and $12 \mathrm{a}$ ), the position of the top of the fill in the syncline represented the local base level for the 
transverse paleovalleys. If the top of the fill is raised above the level of the incised bedrock of the paleovalley, sediments will aggrade within the paleovalley. If, on the other hand, the depositional surface in the growth syncline is low with respect to the bedrock of the paleovalley and if the transverse sediment supply is not high, then continued incision of the transverse valley will occur. Deposition or erosion in the paleovalleys can therefore be interpreted in the context of changes in (1) the balance between the rate of sediment supply to the growth syncline from longitudinal rivers and the rate of subsidence of the syncline and (2) the rate of crestal uplift of the detachment fold versus sediment supply and stream power in the transverse paleovalleys. In the context of these conceptual interactions, incision in the transverse valley is promoted by high rates of subsidence in the growth syncline and of crestal uplift in the fold, low rates of sediment supply to the transverse valley and of accumulation in the growth syncline, and high stream power in the transverse valley. In the study area, the deepest incision of the paleovalley and the development of an unconformity in the growth syncline near the mouth of the transverse valley appear to have occurred when sediment-accumulation rates were at their lowest levels (Figures 2, 7, and 8). Aggradation and backfilling in the paleovalleys are interpreted to be promoted by rapid accumulation in the growth syncline, high rates of sediment supply to the transverse valley, decreases in subsidence in the growth syncline and/or of uplift in the crestal region of the detachment fold, and decreases in stream power in the transverse valley. In the context of the magnetic chronology (Figure 8), the doubling of accumulation rates after $35.7 \mathrm{Ma}$ and a relative slowing of crestal uplift rates in the detachment fold appear to correspond with the switch from incision to infilling in the larger paleovalley.

The minimum topographic relief that can be documented on the larger paleovalley is $\sim 150 \mathrm{~m}$, which represents the stratigraphic separation of the base and the top of the paleovalley fill. The average slope of the preserved valley wall is about $\sim 20^{\circ}$. During the $\sim 1-\mathrm{m}$.y.-long interval when the paleovalley was filling, erosion of the interfluves would have reduced the original relief on the paleovalley to that observable today.

In the case of unit 2 , nearly all of the hanging wall topography developed during growth of the detachment fold and during tightening of the previously formed syncline which was inherited from earlier deformation in the Eocene (Figure 2). In contrast, much of the topographic relief of the Montsec hanging wall is likely to have been inherited. The size of the megaclast within the basal part of unit 3 suggests a minimum of several hundred meters of hanging wall relief during early reactivation of the Montsec thrust. The inclined talus cones of unit 4 that are aligned along the lower part of the Montsec hanging wall indicate that a minimum of $500 \mathrm{~m}$ of relief above the depositional plain existed at the end of thrusting, during which time $\sim 1 \mathrm{~km}$ of shortening and nearly equal amounts of hanging wall uplift took place.

Sequential reconstructions across the deforming Serres Marginals and Montsec thrust sheets (Figure 2) indicate that between $35 \mathrm{Ma}$ and $33 \mathrm{Ma}, 750 \mathrm{~m}$ of shortening (27\%) occurred between the pinning points on the Montsec thrust and the innermost Serres Marginals thrust [Vergés, 1993]. After $\sim 35.6$ $\mathrm{Ma}$, the Montsec footwall was differentially tilted and uplifted, such that the proximal regions were raised $250 \mathrm{~m}$ with respect to coeval, formerly horizontal surfaces only $1 \mathrm{~km}$ away. This uplift was accomplished primarily through folding. Both preexisting folds in the pretectonic strata and newly deposited strata of units 2 and 3 were tightened into chevron geometries displaying $\sim 60^{\circ}$ interlimb angles (Figure 2) [Ramsay, 1974]. This late stage uplift supports a model suggesting that during late stages of deformation, horizontal shortening is often superseded by vertical uplift driven primarily by folding. This phenomenon can generate considerable topographic relief late in the deformational sequence. At Oliana, this thickening and uplift shift the longitudinally flowing river toward the foreland (Figure 2), where it impinges on the northern flank of the Oliana anticline.

Comparison of the reconstructed geometries of the Oliana region with those associated with presently active structures serves to emphasize the importance of relative rates of tectonic, erosional, and depositional processes in controlling the evolution of the landscape. In a structural position analogous to the Oliana anticline with respect to the Ebro basin during the latest Eocene, Wheeler Ridge in the southern San Joaquin valley of California represents the outermost major fold [Medwedeff, 1992] in an active fold-and-thrust belt that borders a large depositional basin. Wheeler Ridge is an eastward plunging anticline that dives below the modern depositional plain at its eastern end (Figure 12b). Its hanging wall has been cut by transverse streams that are localized by transverse faults [Medwedeff, 1992]. Where rates of hanging wall uplift have exceeded rates of incision of the anticline, former water gaps have been converted to wind gaps. On the distal, northern flank of Wheeler Ridge, short-radius (generally $<1 \mathrm{~km}$ ), locally sourced alluvial fans are being actively deformed in their proximal parts by the growing fold. To the south of the fold crest, the depositional plain between the fold and the Pleito thrust is progressively incorporated into the rapidly uplifting backlimb of the growing anticline, where it is attacked by erosional processes. The emergence of Wheeler Ridge above the depositional plain has strongly perturbed the previous depositional systems. Small, transverse streams that had fed into the site of the present wind gap have been diverted to the east, where they join others and are either focused into the water gap or are diverted around the plunging nose of the anticline. The topography on the large alluvial fans near to Wheeler Ridge suggests that they also have been deflected around the growing anticline. On the northern side of the anticline, which is downstream with respect to the regional drainage system, two subregional alluvial fan systems converge (Figure 12b) toward a zone of reduced accumulation: a "depositional shadow zone." To the south of Wheeler Ridge, the active Pleito thrust uplifts the more proximal parts of the thrust belt and causes transverse streams to incise into its hanging wall.

At two scales, Wheeler Ridge displays geometries that are analogous with those reconstructed at Oliana. At the small scale, the transverse valleys in Wheeler Ridge are comparable to the Oliana paleovalleys during stages in which local uplift rates of the fold crest surpassed the accumulation rates on the footwall. At the large scale, Wheeler Ridge presents a major topographic barrier that deflects major drainage systems around it. Similarly, the Oliana anticline acted as a divisive barrier to the ancestral Segre River (Figure 12a) which was diverted either into the broad foreland to its southeast which lacked many topographic barriers or into the structural moat along its northwest flank (analogous to the separation between the Pleito Thrust and Wheeler Ridge).

There are several important differences between Wheeler Ridge and Oliana. First, the major drainage is not open to the west, because the uplifted Pleito hanging wall and Wheeler Ridge intersect toward the west and their mutual uplift rates exceed the rate of aggradation. Consequently, Wheeler Ridge cannot divert a major river system to either flank, as happens at Oliana. Second, whereas the depositional area above the submerged eastern fold nose probably provides an excellent model for overlapping syntectonic geometries (Figure $5 b$ ), for much of the length of 
Wheeler Ridge, the rate of crestal uplift $(3.2 \mathrm{~m} / \mathrm{kyr})$ is considerably greater than the rate of sediment accumulation $(1.8 \mathrm{~m} / \mathrm{kyr})$ adjacent to the anticline [Medwedeff, 1992]. As a result, rather than developing gradually tapering syntectonic beds that are incorporated and recognizable in the forelimb as is seen in the detachment fold at Oliana, syntectonic strata at Wheeler Ridge pinch abruptly against the forelimb and display such strong offlap (Figure 5c) that they can not clearly be seen as incorporated into the growing fold. Third, the presence of readily eroded marl in the core of the Oliana anticline inhibits recognition, on the distal side of the fold, of fans with locally derived clasts that would be analogous to those at Wheeler Ridge.

When both the differences and similarities between Oliana and Wheeler Ridge are considered, they define a spectrum of responses to active contractional deformation. At Wheeler Ridge, an ergodic substitution of space for time serves to delineate likely responses of the landscape to varying rates of uplift and aggradation. These spatially variable rates produce depositional and topographic geometries that mimic many of those that result from the temporally varying rates and processes, such as those defined at Oliana. The modern environment of Wheeler Ridge serves to define more clearly surficial relationships between structure, topography, and sedimentation, whereas the ancient setting of Oliana permits one to view the depositional, erosional, and structural geometries that are presently obscured beneath the Earth's surface at Wheeler Ridge.

\section{Conclusions}

Depositional and topographic patterns at Oliana developed in response to thrusting, growth of a detachment fold, anticlinal uplift, and continued deformation of previously folded structures during late Eocene times. Our analysis shows the following:

1. Along the deformational front, there exists an interplay between longitudinally flowing rivers from distant sources and transversely flowing rivers of local origin. In regions where the eroding hanging walls comprise resistant strata and are characterized by relatively small catchments, the transverse contribution to the sedimentary record will be diminished. Where there is high topography on hanging walls inherited from earlier deformation, however, large landslide blocks can tumble into footwall synclines.

2. Folding associated with both the forelimbs and backlimbs of growing structures causes related thinning and deformation of syntectonic strata. The resulting wedge-shaped geometries of syntectonic strata open both toward the foreland and the hinterland and record fold growth.

3. When folding and crestal uplift are rapid in comparison to the rate of aggradation, relief of the hanging wall above the depositional plain increases, transverse valleys become accentuated, strong offlap occurs in depositional zones, and proximal unconformities may develop as older syntectonic strata are folded, uplifted, and exposed to erosion.

4. Transverse paleovalleys are localized by the structure and lithology into which they are incised. The cores of folds and weakly resistant strata provide favored pathways. At Oliana, resistant limestones uphold the valley walls, and synclinal folds have been exploited by the paleovalleys. When crestal uplift rates are only a few millimeters per year, paleovalley incision can sometimes keep pace with uplift. The topographic relief on such paleovalleys at Oliana is $>150 \mathrm{~m}$. The transition from incision to deposition within a paleovalley is apparently controlled by accelerating rates of aggradation in comparison to hanging wall uplift.
During filling of the transverse paleovalleys, local source areas are almost exclusively represented.

5. When aggradation is rapid in comparison to uplift, growing structures and any preexisting topography can be onlapped or overlapped by syntectonic strata. At Oliana, accumulation rates of $\sim 25 \mathrm{~cm} / \mathrm{kyr}$ are sufficiently rapid to create strong onlap. Near equality in rates of accumulation and uplift lead to conspicuous thinning and folding of syntectonic strata into a growth syncline (progressive unconformity).

6. Large-scale geometries of strata within growth synclines also depend on the erosion of the crestal area of the adjacent fold. When the crest remains intact, continuous deposition and folding are often recorded by the syntectonic strata in the forelimb. In contrast, when the crest is breached, secondary unconformities can develop within the growth synclines due to lowered transverse gradients along paleovalleys, especially during times of low accumulation and rapid subsidence in the syncline.

7. Very similar structural geometries can be found through a comparison of the Oliana area with the presently deforming Wheeler Ridge in southern California. This modern analog of a plunging anticline impinged upon by hindward thrust sheets displays many of the same features that have been reconstructed for the Oliana area, including structurally controlled transverse paleovalleys and structurally diverted drainages. The main differences between these two settings result from the more rapid rates of crestal uplift at Wheeler Ridge which results in pronounced offlap of many syntectonic strata and in the development of pronounced topographic barriers to flow. Whereas modern analogs can display unambiguous modern geomorphic relationships, the record of their previous deformational and depositional history is often obscured in the subsurface. Although geomorphic processes and topography at ancient sites can only be reconstructed, rather than observed, stratigraphic and structural exposures provide the opportunity to document the temporal evolution of the structure and the landscapes related to its deformation.

Acknowledgments. This research was partially supported by grants EAR8816181 and 9018951 from the National Science Foundation and grants from the Petroleum Research Fund (ACS-PRF 20591, 17625, and 23881 ) to D.W.B. J.V. received support for this study from the Subprograma de Perfeccionamiento para Doctores y Tecnólogos (1990) and DGICYT projects PB91-0252 and PB91-0805. Discussions with A. Meigs and J. Friedmann have served to improve this paper significantly. Very thorough and helpful reviews by J. K. Snow, D. J. Harbor, and M. Ellis greatly improved this manuscript.

\section{References}

Burbank, D.W, and R.A. Beck, Models of aggradation versus progradation in the Himalayan foreland, Geol. Rundsch., 80, 623-638, 1991.

Burbank, D.W., J. Vergés, and J.A. Muñoz, Coeval hindward- and forward-imbricating thrusting in the central southern Pyrenees: Timing and rates of shortening and deposition, Geol. Soc. Am. Bull, 104, 1-18, 1992.

Cande, S.C., and D.V. Kent, A new geomagnetic polarity time scale for the Late Cretaceous and Cenozoic, J. Geophys. Res., 97, 13,91713,953, 1992.

Eisbacher, G.H., M.A. Carrigy, and R.B. Campbell, Paleodrainage pattern and late orogenic basins of the Canadian Cordillera, in Tectonics and Sedimentation, edited by W.R. Dickinson, Soc. Econ. Paleontol. Mineral. Spec. Publ., 22, 143-166, 1974.

England, P., and P. Molnar, Surface uplift, uplift of rocks, and exhumation of rocks, Geology, 18, 1173-1177, 1990.

Hein, F.J., Deep-sea and fluvial braided channel conglomerates: a 
comparison of two case studies, in Sedimentology of Gravels and Conglomerates, edited by E.H. Koster and R.J. Steel, Mem.. Can. Soc. Pet. Geol., 10, 33-50, 1984.

Martinez-Peña, M.B., and J. Pocoví, El amortiguamiento frontal de la estructura de la coberta surpirenaica y su relación con el anticlinal de Barbastro-Balaguer, Acta Geol. Hisp., 23, 81-94, 1988.

Medwedeff, D.A., Geometry and kinematics of an active, laterally propagating wedge thrust, Wheeler Ridge, California, in Structural Geology of Fold and Thrust Belts, edited by S. Mitra and G.W. Fisher, pp. 3-28, Johns Hopkins University Press, Baltimore, Md.,1992.

Muñoz, J.A., Evolution of a continental collision belt: ECORS-Pyrenees crustal balanced section, in Thrust Tectonics, edited by K.R. McClay, pp. 235-246, Chapman and Hall, London, 1992.

Nemec, W. and R.J. Steel, Alluvial and coastal conglomerates: their significant features and some comments on gravelly mass-flow deposits, in Sedimentology of Gravels and Conglomerates, edited by E.H. Koster and R.J. Steel, Mem. Can. Soc. Pet. Geol, 10, 1-32, 1984.

Puigdefábregas, J., J.A. Muñoz, and J. Verges, Thrusting and foreland basin evolution in the Southern Pyrenees, in Thrust Tectonics, edited by K.R. McClay, pp. 247-254, Chapman and Hall, London, 1992.

Ramsay, J.G., Development of chevron folds, Geol. Soc. Am. Bull., 85, 1741-1754, 1974

Riba, O., Syntectonic unconformities of the Alto Cardener, Spanish Pyrenees: A genetic interpretation, Sediment. Geol., 15, 213-233, 1976.

Séguret, M., Étude tectonique des nappes et séries décollées de la partie centrale du versant sud des Pyrénées, Publ. Univ. Sci. Tech. Langeduc, Sér. Geol. Struct., 2, 1-155, 1972.

Smith, G.A., Sedimentology of proximal to distal volcanoclastic dispersed across and active foldbelt: Ellensburg Formation (late Miocene), central Washington, Sedimentology, 35, 953-978, 1988.
Vergés, J., Estudi geològic del versant sud del Pirineu oriental i central: Evolució cinemática en 3D, Ph.D. thesis, 203 pp., Univ. of Barcelona, 1993.

Vergés, J. and D.W. Burbank, Eocene-Oligocene thrusting and basin configuration in the eastem and central Pyrenees (Spain), in Tertiary Basins of Spain, edited by P.F. Friend and C.J. Dabrio, Cambridge University Press, New York, in press, 1994.

Vergés, J. and Muñoz, J.A., Thrust sequences in the southern central Pyrenees, Bull. Soc. Geol. Fr.,8, 265 - 271, 1990.

Vergés, J., J.A. Muñoz, and A. Martinez, South Pyrenean fold-and-thrust belt: Role of foreland evaporitic levels in thrust geometry, in Thrust Tectonics, edited by K.R. McClay, pp. 255-264, Chapman and Hall, London 1991.

Wallace, R.E., Geometry and rates of change of fault-generated range front, north-central Nevada, U. S. Geol. Surv. J. Res., 6 637-650, 1978.

West, R.B., Tectonic geomorphology, landform modelling, and soil chronology of alluvial fans of the Tejon embayment, southemmost San Joaquin Valley, Califomia, M.Sc. thesis, 148 pp., Univ. of Calif., Santa Barbara, 1991.

D. W. Burbank, Department of Geological Sciences, University of Southem California, Los Angeles, CA 90089. (email: Internet: burbank@coda.usc.edu)

J. Vergés, Departamento de Geologia Dinàmica, Geofísica, i Paleontologia, University of Barcelona, 08071 Barcelona, Spain. (e-mail: Internet: jaumev@natura.geo.ub.es)

(Received April 23, 1993; revised January 5, 1994; accepted February 14, 1994.) 